\title{
Smallpox in Africa during Colonial Rule
}

\author{
WILLIAM H SCHNEIDER*
}

The history of smallpox in Africa during colonial rule is a relatively neglected subject. This is not because of ignorance or obscurity but in some ways just the opposite: it is thought that there is little more to be learned about it. To be sure, vaccination campaigns during colonial rule were one of the earliest and most extensive public health programmes that Europeans bragged about as evidence of the advantages of colonial rule: "an appreciable agent of propaganda", is how one French colonial medical officer described smallpox vaccination. ${ }^{1}$ The mass campaigns used mostly African personnel and produced effective results. Moreover, at the end of colonial rule and beginning of independence, smallpox gained worldwide attention when the World Health Organization (WHO) launched its smallpox eradication programme. Now the colonial measures were criticized as not going far enough, and data on epidemics and prevalence were the subject of much study as measures were taken which successfully eliminated the scourge in the 1960s and early 1970s.

Since then, the magisterial volume by the principal leaders of that effort, Frank Fenner, and his co-authors, has been taken as more or less the last word on the subject, not just in Africa but worldwide. This is appropriate, to a large extent. The sections on Africa in the volume, and another by one of their collaborators, Donald Hopkins, are thoroughly documented, based on a large amount of evidence, and certainly the starting point for anyone wishing to revisit the subject. ${ }^{2}$ But these authors have a particular point of view, given their involvement in the campaign, which minimizes earlier efforts. Hence the chapters on colonial rule focus primarily on the epidemiology of smallpox, with little about attempts to prevent or respond to epidemics when they occurred. ${ }^{3}$

This study focuses on the efforts at smallpox control and prevention from the 1920s to the end of colonial rule in West, Central and East Africa. These were by far the earliest and for a long time the largest efforts at introducing Western medicine to Africa. To the

(C) William H Schneider 2009

*William H Schneider, PhD, Professor and Baker-Ort Chair in International Healthcare Philanthropy, Department of History, Indiana University, 425 University Blvd., Indianapolis, IN 46202, USA; e-mail: whschnei@iupui.edu

The author wishes to acknowledge support from the Center on Philanthropy at Indiana University, editorial assistance from Vanessa D“Amico, plus the help of librarians and archivists too numerous to mention.

\footnotetext{
${ }^{1}$ Claude Chippaux, 'Le Service de santé des troupes de marine', Médecine Tropicale, 1980, 40: 614.
}

\footnotetext{
${ }^{2}$ For the official WHO history of the smallpox eradication campaign, see F Fenner, D A Henderson, I Arita, Z Ješek, and I D Ladnyi, Smallpox and its eradication, Geneva, World Health Organization, 1988; Donald R Hopkins, Princes and peasants: smallpox in history, University of Chicago Press, 1983.

${ }^{3}$ The sources used by Hopkins and Fenner, et al., for the period before the WHO campaign were mainly secondary which, in turn, relied on data collected by the League of Nations and WHO or accounts by doctors in the field at the time. They did not use archival reports and colonial government records.
} 


\section{William H Schneider}

extent they succeeded, even though not completely, they were a model for further public health efforts, including the WHO eradication campaign. To the extent that they failed, the campaigns offer a lesson for contemporary efforts to reduce, let alone eradicate, diseases in tropical settings.

In addition to showing the extent of smallpox vaccination in colonial Africa, this study also examines assessments at the time about the effectiveness of such attempts at control and prevention and the wider context in which they were undertaken. It supports the most important lesson drawn by those involved in the WHO eradication campaign: that only a worldwide and comprehensive effort could succeed in eliminating the periodic epidemics that plagued places such as Africa. Without sufficient vaccination protection, even if a particular colony had no new cases for a number of years, isolated cases or smallpox brought in by travellers from outside eventually reached small pockets of those unvaccinated, with devastating results. That did not mean authorities before 1958 did not try, and those efforts show significant success in containing and eliminating outbreaks when they occurred.

After the eradication of smallpox, there were great hopes of eliminating other contagious diseases. ${ }^{4}$ This not only failed to occur but new diseases, such as HIV/AIDS, have emerged which means we are back in a situation of trying to control and eliminate diseases, much as colonial authorities attempted in the first half of the twentieth century in Africa. A re-examination of their efforts is therefore warranted.

\section{The Epidemiology of Smallpox in Africa during Colonial Rule}

Africa was one of the places in the world where smallpox remained the longest and was most highly endemic. In the first half of the twentieth century, only Asia, where India and Pakistan had a much more concentrated population, exceeded Africa in numbers of cases. Table 1 shows official WHO statistics in the first years after the World Health Assembly voted to eradicate smallpox. The incidence of smallpox in Africa, however, was much higher than in the Asian sub-continent. Table 2 shows figures at

Table 1

Smallpox cases reported by continent, 1959-1961

\begin{tabular}{lrrr}
\hline Continent & 1959 & 1960 & 1961 \\
\hline Africa & 15,781 & 16,127 & 24,182 \\
America & 4,899 & 5,531 & 8,168 \\
Asia & 60,749 & 39,251 & 52,217 \\
Europe & 15 & 47 & 27
\end{tabular}

Source: 'Development of the smallpox eradication programme', WHO Chronicle, 1967, 21 (9): 389-93, on p. 389.

\footnotetext{
${ }^{4}$ In fact, this has been an ongoing debate ever since. See, for example, D R Hopkins, 'After smallpox eradication: yaws?', Am. J. Trop. Med. Hyg., 1976, 25 (6): 860-5, and I Arita, J Wickett,
}

M Nakane, 'Eradication of infectious diseases: its concept, then and now', Jpn J. Infect. Dis., 2004, 57 (1):1-6. 


\section{Smallpox in Africa during Colonial Rule}

Table 2

Smallpox incidence rates in countries reporting more than 500 cases in 1962

\begin{tabular}{lrlr}
\hline Country & Approx. rate/100,000 & Country & Approx. rate/100,000 \\
\hline In Africa & & In Asia & \\
Cameroon & 20 & India & 10 \\
Chad & 35 & Indonesia & 1 \\
Congo (Brazza) & 144 & Pakistan & 4 \\
Congo (Leo) & 29 & & \\
Guinea & 100 & \\
Ivory Coast & 58 & \\
Mali & 38 & \\
Niger & 34 & \\
Nigeria & 11 & \\
Rhodesia \& Nyasaland & 12 & \\
Tanganyika & 10 & \\
Togo & 38 & \\
Uganda & 10 & \\
Upper Volta & 30 & \\
\hline
\end{tabular}

Source: World Health Organization, WHO Expert Committee on Smallpox: first report, Technical Report Series No. 283, Geneva, World Health Organization, 1964, p. 8.

the end of colonial rule and beginning of independence for the main countries in West, Central, and East Africa in comparison to countries of Asia.

Using figures from annual epidemiological reports of the League of Nations and WHO, Figure 1 (this and subsequent figures are in the Appendix, pp. 218-27) shows that there were between 15,000 and 30,000 cases of smallpox reported for most years in Africa from 1928 to $1966 .{ }^{5}$ This graph shows broadly that even as epidemics of smallpox came and went, there was otherwise a surprisingly steady prevalence. Also of note is the sharp increase of smallpox during the Second World War when large numbers of men were mobilized for military service. The other increases and declines suggest periodic but brief outbreaks or epidemics, but it is difficult to understand the epidemiology without focusing on smaller geographical areas. Before examining the incidence of smallpox at the colony level, it is useful to comment on the sources and reliability of these statistics and those that follow.

On the surface, there is little to inspire confidence in the historical accuracy of health statistics in Africa, given the lack of infrastructure and trained personnel to do record keeping. For example, one often repeated reference in the literature on the history of smallpox is to only a 5 per cent reporting rate. ${ }^{6}$ Closer analysis reveals, however, that

\footnotetext{
${ }^{5} \mathrm{~J} \mathrm{~L}$ Tulloch, 'The last 50 years of smallpox in Africa', WHO Chronicle, 1980, 34 (11): 407-12. See also, Fenner, et al., op. cit., note 2 above, p. 393; W H Foege, J D Millar, and D A Henderson, 'Smallpox eradication in West and Central Africa',
}

Bull. World Health Organ., 1975, 52 (2): 209-22, p. 211.

${ }^{6}$ Tulloch, p. 408; Foege, et al., p. 211, both in note 5 above. One of the strongest charges of under reporting of smallpox is, D A Henderson, 'The 


\section{William H Schneider}

this citation, by researchers who worked in the WHO eradication programme, was to an unpublished report with few or no serious studies attempting corroboration.

Reassurances by colonial administrators about the accuracy of health data are firm, if not very convincing. In the Belgian Congo, for example, the administration prided itself on surveillance of smallpox. By the 1930s the Governor-General claimed he was notified by telegram of every case of smallpox diagnosed in the colony. In some years, however, the annual medical report for the colony simply stated, "the number of vaccinations is probably higher because numerous missions and some administrators have not supplied statistics". ${ }^{7}$ Overall, however, the consistency of data is striking from different regions and colonial administrations, whether it be common fluctuations of cases, death rates (surprisingly steady around the average of 8 per cent, although with some significant deviations), or percentage of vaccinations that tested positive after revaccination. ${ }^{8}$ Moreover, as several field workers have noted about smallpox, cases were easily detectable, thanks to the symptoms of rashes and pockmarking, and Africans were familiar with the disease and generally eager to receive treatment and vaccination. ${ }^{9}$

The number of cases of smallpox reported in British, French and Belgian colonies in Africa reflect the local variations making up the broad ebb and flow of smallpox outbreaks during the 1940s and 1950s as shown in Figure $1 .{ }^{10}$ For example, in any given colony, the fluctuations in smallpox cases could be frequent and extreme. Indeed, all British colonies and territories examined, except the two largest (Nigeria and Tanganyika) came close to or succeeded in eliminating smallpox for successive years on end. Yet within a year or two, they had outbreaks of several thousand cases: Sierra Leone in 1933 and 1957; Gold Coast, 1942; Kenya, 1934 and 1943; Uganda, 1944, Northern Rhodesia, 1945 and 1955. Figures 2 to 6 show the periodic epidemics in these British colonies.

eradication of smallpox', Scientific American, 1976, 235 (4): $25-33$.

${ }^{7}$ Belgium. Ministère des Affaires Etrangères. Archives Africaines (hereafter AA), RA/MED 82, Colonie du Congo belge, 'Rapport sur l'hygiène pendant l'année 1927', p. 86. This was an exception. In fact, archival reports are surprisingly thorough, often with monthly reports by region in colonies. For copies of telegrams in folders, see AA, A11 Hygiene, 4402 Variole.

${ }^{8}$ Tulloch, op. cit., note 5 above, p. 408. In addition, the infrequent cases of inaccurate or incomplete data are obvious. For example, between 1936 and 1941 there was a dramatic drop in the incidence of death from smallpox reported in French West Africa. This was not, however, the result of an under-reporting of deaths, because figures from neighbouring British colonies also show a dramatic decline both in cases as well as deaths from smallpox as the epidemic of the mid-1930s subsided. The error was more probably in over-reporting of smallpox cases in French West Africa rather than in underreporting deaths. This, in fact, was the conclusion of a review of these statistics in a subsequent colonial health report. See l'Institut de médecine tropicale du
Service de santé des armées (hereafter IMTSSA), Box 84, folder 'Service de santé, AOF. Direction de la Santé,, 'Rapport sur le fonctionnement du Service de Santé, 1953', pt. II, p. 43.

${ }^{9}$ Thomas Mack, 'A different view of smallpox and vaccination', N. Engl. J. Med., 2003, 348 (5): 460-3, p. 460, who worked on the eradication effort in Pakistan in the early 1970s, recalled, "The physical appearance of an unvaccinated person with variola major is alarming and quite unlike anything else, including the appearance of persons with varicella." D G Conacher, 'Smallpox in Tanganyika 1918-1954', East Afr. Med. J., 1957, 34 (5): 157-81, pp. 160-1, pointed out errors and difficulties in diagnosis and notification, but concluded, "Cases have not necessarily been diagnosed by qualified doctors but it may be assumed that, before it is actually recorded by the Medical Department, the diagnosis is a fairly reliable one."

${ }^{10}$ Sources for the graphs that follow come from annual reports of medical departments of colonies, supplemented by League of Nations and WHO statistics as cited in Fenner, et al., op. cit., note 2 above. 


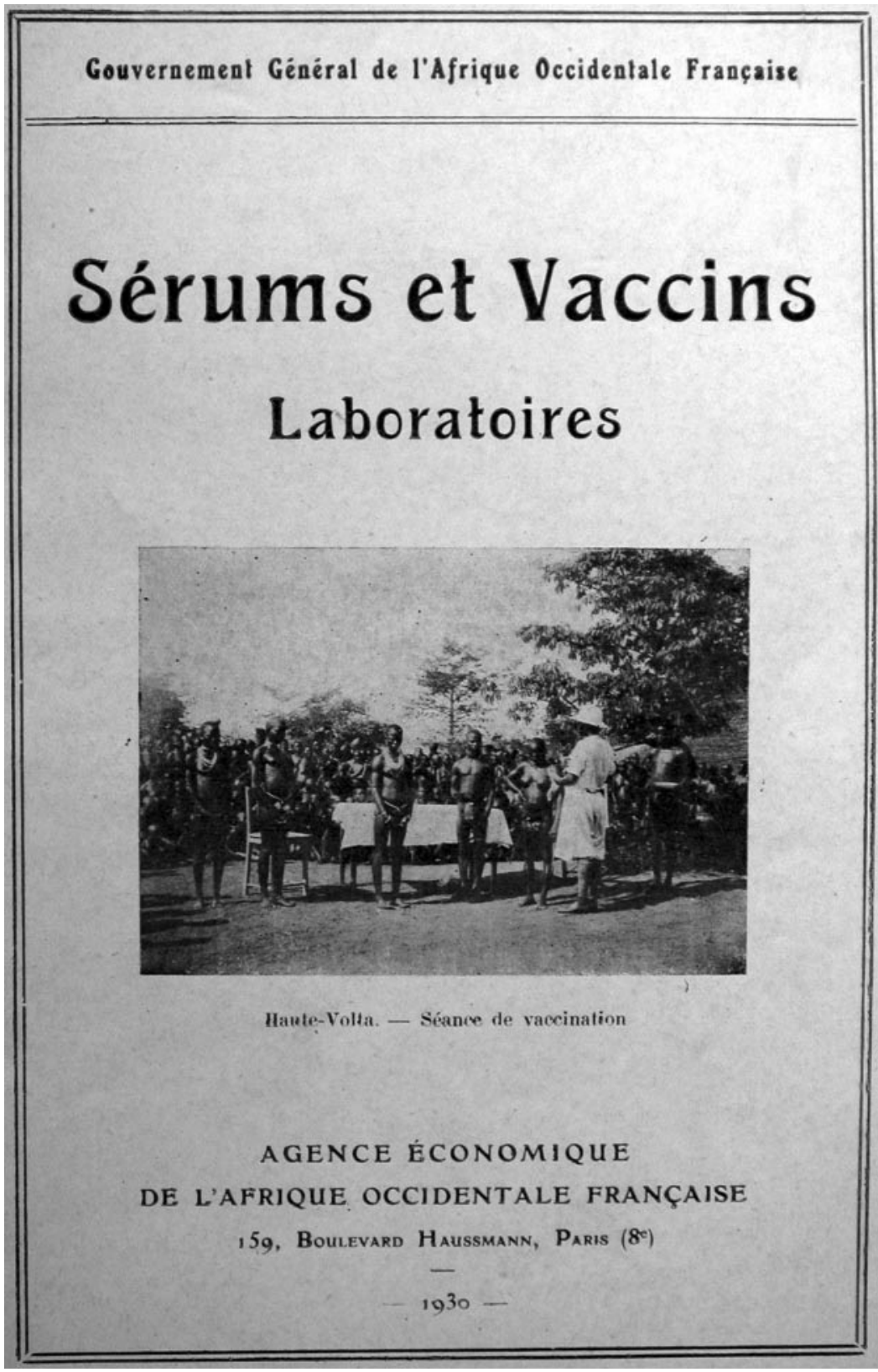

Cover of 1930 manual of vaccination in French colony of Upper Volta.

Source: Gouvernement Général de l'Afrique Occidentale Française, Sérums et vaccins Laboratoires, Paris, Agence Économique de l'Afrique Occidentale Française, 1930, front cover. 


\section{William H Schneider}

Tanganyika (Figure 7) had more cases, being a larger colony, but it was more similar to these smaller British colonies than Nigeria, whose population size and density clearly put it in a category by itself. Only twice did the annual number of reported cases in Nigeria drop below 2,000 between 1927 and 1958, with an average closer to 8,000 (median 5,700) and reaching tens of thousands of cases during the immediate postSecond World War years (20,940 in 1950, see Figure 8).

Reports of smallpox cases in French West African colonies also varied widely depending on time and place. ${ }^{11}$ Smallpox in French Equatorial Africa (AEF) was not as prevalent, except for Chad. The mandate territory of Cameroon was large enough occasionally to report significant numbers of smallpox cases. There was generally a rise in cases in the mid-1930s, the mid-1940s, and early and late 1950s, as illustrated in Figure 9 for French West Africa. There was also much variation between individual colonies. Senegal and Cameroon (Figures 10 and 11) remained relatively free from smallpox with only a handful of years between 1925 and 1958 when there were more than 400 cases of smallpox reported in these colonies (four times in Senegal and three times in Cameroon) and some consecutive years with none or less than ten cases (eight years in Senegal and thirteen in Cameroon). The Ivory Coast and Dahomey (Benin), were also spared serious epidemics until after the Second World War (Figures 12 and 13). In contrast, smallpox in Guinea, Niger, the French Soudan and Chad (Figures 14 to 17) which shared a similar climate and traditional east-west trade routes, followed the pattern of more frequent rise and fall seen in many British colonies, and an overall higher prevalence.

Finally, the reports of smallpox cases in the Belgian Congo (Figure 18) show a similarity to those from the larger British colonies. They indicate periodic outbreaks in the late 1920s as well as during and after the Second World War. In such a large and diverse colony there was no time when cases came close to being eliminated. If anything, there was a persistence of high prevalence until the end of the 1950s, with an average of 3,756 cases reported annually from 1950 to 1958 , and a median of 4,591.

\section{Smallpox Vaccination and Other Modern Medical Care in Africa}

Variolation, a traditional form of inoculation against smallpox, was practised in Africa well before colonial rule began. ${ }^{12}$ The method was to pass the disease "from arm to arm", as described in the following first-hand account by a Hausa woman recalling her childhood in the 1890s, "They used to scratch your arm until the blood came, then they got the fluid from someone who had the smallpox and rubbed it in. It all swelled up and you covered it until you healed. Some children used to die; your way of doing it is better." ${ }^{\prime 13}$ In fact, this practice became a problem for colonial medical campaigns, because in an effort to provide protection, it spread the disease.

Campaigns against infectious diseases began shortly after the European "scramble for Africa" which occurred at the same time that "tropical medicine" was established as a

\footnotetext{
${ }^{11}$ This includes Senegal, Mauretania, Guinea, Ivory Coast, French Soudan (now Mali), Upper Volta (now Burkina Faso), Niger, and Dahomey (now Benin). Togo and Cameroon were administered as mandate territories with statistics kept separately.
}

\footnotetext{
${ }^{12}$ Eugenia W Herbert, 'Smallpox inoculation in Africa', J. Afr. Hist., 1975, 16 (4): 539-59.

${ }^{13}$ Mary Smith, Baro of Kano, London, 1954, p. 46, as cited in Herbert, p. 544.
} 


\section{Smallpox in Africa during Colonial Rule}

field. The two were obviously related in that colonies provided a new venue for medical practice and research, but the field was equally shaped by another concurrent development: the emergence of the germ theory of disease. ${ }^{14}$ In 1882 Koch announced his discovery of the tubercle bacillus in Berlin, the city that two years later hosted the conference that drew up ground rules for European claims to rule in Africa. One after another, researchers from Germany, France, Britain and Italy, tracked down the causes of the ages-old infectious disease scourges such as cholera, malaria, and yellow fever in exotic settings such as Egypt, China, Cuba and India.

Smallpox was different. Its cause, or at least a method of prevention, had been known for hundreds of years, and by the time that Europeans moved in to occupy Africa, they had almost a century of experience with Jenner's much improved method of vaccination back home. By 1900, smallpox had dramatically declined in a number of European countries, including all those with colonies in Africa, thanks largely to systematic vaccination and revaccination programmes with glycerated calf-derived vaccine. ${ }^{15}$ It is, therefore, not surprising that smallpox vaccination quickly became one of the first and most widely practised medical interventions in African colonies.

Even before the turn of the twentieth century, the French reported inoculation campaigns in Senegal and what later came to be called the French Soudan (present-day Mali). ${ }^{16}$ In 1902, France passed a mandatory smallpox vaccination law which two years later was also applied to the colonies, and in 1905 systematic vaccinations began in French West Africa. In the Belgian Congo smallpox vaccination was required for all urban residents as early as 1894 , and in 1920 vaccinations were made mandatory in the British colony of the Gold Coast. ${ }^{17}$

As colonial medical services expanded between the wars and especially after 1945, smallpox campaigns grew along with them. Other efforts of care and prevention also grew but were still overshadowed in terms of numbers reached. For example, a 1954 health service report for French West Africa listed over 3.6 million mixed smallpox-yellow fever vaccinations and another 1.6 million for smallpox only, while there were only 87,529 inoculations for yellow fever only, and 53,994 for tuberculosis (BCG). ${ }^{18}$

There were mass treatment campaigns in colonial Africa for only a few diseases on a scale approaching that of smallpox prevention efforts: notably sleeping sickness and

\footnotetext{
${ }^{14}$ See Michael Worboys, 'The emergence of tropical medicine: a study in the establishment of a scientific discipline', in G Lemaine, et al. (eds), Perspectives on the emergence of scientific disciplines, The Hague, Mouton, 1976, pp. 75-98; and Jean-Paul Bado (ed.), Les conquêtes de la médecine moderne en Afrique, Paris, Karthala, 2006.

${ }^{15}$ Fenner, et al., op. cit., note 2 above, p. 320.

${ }^{16}$ For a good but not exhaustive survey of these efforts, see Hopkins, op. cit., note 2 above, pp. 194-7. For the broader context of health in Senegal, see Angélique Diop, 'Les débuts de l'action sanitaire de la France en AOF, 1895-1920: le cas de Sénégal', in Charles Becker, Saliou Mbaye and Ibrahima Thioub
}

(eds), AOF: réalités et héritages, Dakar, Direction des Archives du Sénégal, 1997, vol. 2, pp. 1212-27.

${ }^{17}$ AOF, 'Rapport, 1953', op. cit., note 8 above, pp. 36, 42-4; Mary-Inez Lyons, 'Public health in colonial Africa: the Belgian Congo', in Dorothy Porter (ed.), The history of public health and the modern state, Clio Medica, 26, Amsterdam, Rodopi, 1994, pp. 356-84, on p. 365; Gold Coast Colony, Report on the Medical Department, 1933-34, Accra, Gold Coast, Government Press, 1934, p. 5 (hereafter Gold Coast, Report, with relevant date).

${ }^{18}$ IMTSSA Box 84, AOF Directeur général de la Santé publique, 'Rapport sur le fonctionnement du Service de Santé, 1954, pt. 1', p. 28. 


\section{William H Schneider}

Table 3

Vaccinations in French West Africa, 1954

Disease

Plague

Cholera

Yellow fever

Smallpox-yellow fever mixed

Smallpox only

Typhus

T.A.B.D.T. (typhoid, paratyphoid, tetanus)

Tetanus

Rabies

Typhoid

BCG (anti-tuberculosis)
Numbers Vaccinated

1,234

914

87,529

$3,614,142$

$1,625,518$

242

1,762

730

1,032

552

53,994

Source: IMTSSA Box 84, AOF Directeur geńéral de la Sante' publique, 'Rapport sur le fonctionnement du Service de Sante', 1954, pt. 1', p. 28.

venereal disease. ${ }^{19}$ For example, the Belgian Red Cross began medical service in Orientale Province of the Congo in 1925. This quickly grew into two hospitals in Pawa (later moved to Viadana) and Wamba, serving 320, 000 people. They reported statistics for venereal disease injections rising from over 70,000 when the programme began in 1930 to almost 200,000 by 1936 (Table 4). ${ }^{20}$ In Kenya a similar programme began in 1922, treating approximately 125,000 Africans for yaws by $1931 .^{21}$

Post-war statistics were higher but of the same order of magnitude. In Kivu province of the Belgian Congo, the 1947 public health report stated there had been 295,239 injections for syphilis and yaws, as compared to 334,684 smallpox vaccinations during the year. For 1951, the number of venereal disease injections in the province grew $(496,438)$ to surpass smallpox vaccinations $(477,931){ }^{22}$

French campaigns against sleeping sickness began in Equatorial Africa during the First World War, led by Eugène Jamot and a team of doctors and auxiliaries which was novel in that it travelled the countryside to diagnose and treat the disease. ${ }^{23}$

\footnotetext{
${ }^{19}$ Of these, sleeping sickness has attracted the most attention from scholars. For example, see MaryInez Lyons, 'Sleeping sickness and public health in the Belgian Congo, 1903-1930', Soc. Soc. Hist. Med. Bull., 1986, 39: 44-6; M Worboys, 'The comparative history of sleeping sickness in east and central Africa', Hist. Sci., 1994, 32 (95 part 1): 89-102. Koch himself was involved in the campaign in Tanganyika. See W U Eckart, 'The colony as laboratory: German sleeping sickness campaigns in German East Africa and in Togo, 1900-1914', Hist. Philos. Life Sci., 2002, 24 (1): 69-89. Malaria, although early recognized as widespread, has been less studied. See Maureen Malowany, 'Targeting malaria in East Africa: debates, dilemmas and developments of the
}

twentieth century', in Bado (ed.), op. cit., note 14 above, pp. 71-98.

${ }^{20}$ Brussels. Archives Royale de Belgique, Archives of Belgian Red Cross, Congo Red Cross (hereafter CRC), RK Congo Box 1, 'Rapport d'activité de la Croix-Rouge du Congo', 1930-1936.

${ }^{21}$ M H Dawson, 'The 1920s anti-yaws campaigns and colonial medical policy in Kenya', Intern. J. Afr. Hist. Stud., 1987, 20 (3): 417-35, p. 425.

${ }^{22}$ AA RA/MED 15, Province de Kivu, 'Rapport sur l'hygiène publique année 1947', pp. 20-1; 1951, pp. 40, 107.

${ }^{23}$ For a recent reappraisal of Jamot and one of his counterparts who led a campaign in Congo, see P G Janssens, 'Eugène Jamot et Emile Lejeune, pages 


\section{Smallpox in Africa during Colonial Rule}

\section{Table 4}

Belgian Red Cross reports of neosalvarsan injections for venereal disease Pawa/Viadana and Wamba Hospitals in Orientale Province, Congo, 1930-36

\begin{tabular}{llrr}
\hline Year & Pawa/Viadana & Wamba & Total \\
\hline 1930 & 37,626 & 35,746 & 73,372 \\
1931 & 27,356 & 52,778 & 80,134 \\
1932 & 20,806 & 52,489 & 73,295 \\
1933 & 26,769 & 54,261 & 81,030 \\
1934 & 42,491 & 94,211 & 136,702 \\
1935 & & & 198,832 \\
1936 & 50,938 & 147,894 & 12 \\
\hline
\end{tabular}

Source: Brussels. Archives Royale de Belgique, Archives of Belgian Red Cross, Congo Red Cross, RK Congo Box 1, 'Rapport d'activité de la Croix-Rouge du Congo', 1930-1936.

After the war he moved to Cameroon, recently taken over from Germany, where he established a similar mobile team. In 1932 after a highly publicized accusation of inappropriate treatment, Jamot went briefly to French West Africa but failed to establish a similar programme. Shortly before the outbreak of the Second World War, Gaston Muraz began a campaign using this model against sleeping sickness, called the Service général autonome de la maladie du sommeil (SGAMS) which operated in French West Africa and Togo. In 1945, its name was changed to Service général d'hygiène mobile et de prophylaxie (SGHMP), because it had already begun vaccinations against smallpox and yellow fever, as well as providing diagnosis and treatment for sleeping sickness.

The numbers receiving treatment increased accordingly. For example, in 1951 the SGHMP treated 410,000 cases of syphilis and 162,000 cases of yaws. ${ }^{24}$ Later in the 1950s, when penicillin became cheap enough, UNICEF and WHO sponsored mass injection campaigns against yaws in Africa. The annual number of those treated during the campaign ranged from 615,000 per year in Ghana, to 925,000 in French West Africa and one million in Nigeria, according to WHO and UNICEF reports. ${ }^{25}$

Although the number of treatments for these other diseases approached the magnitude of the smallpox vaccinations in some instances, none were sustained at such a high level for such a long period. By 1951 between 3 and 5 million smallpox vaccinations were given each year in Nigeria and in French West Africa (see Figures 8 and 9). To summarize, the growth in total vaccinations for selected years in the French, British and Belgian

d'histoire', Annales de la Société Belge de Medecine Tropicale, 1995, 75 (1): 1-12. On public health in French West African colonies just before independence, see Jean-Paul Bado, 'Santé et politique en AOF à l'heure des independences (1939-1960)', in Becker, et al. (eds), op. cit., note 16 above, pp. 1242-59.

${ }^{24}$ See special issue of AOF magazine, Santé publique en A.O.F., 1951, p. 12. On the French services, see Jean-Paul Bado, Origine du Service des grandes endémies. Naissance de l'Organisation de coordination et de coopération dans la lutte contre les grandes endémies (OCCGE), Bobo-Dioulasso OCCGE, 1993, and Paul Richet, '1'Histoire et l'oeuvre de 1'O.C.C.G.E. en Afrique Occidentale francophone', Trans. R. Soc Trop. Med. Hyg., 1965, 59: $234-54$.

${ }_{25}$ 'Communicable diseases in Africa: some facts and Figures', WHO Chronicle, 1959, 13: 82-3. 


\section{William H Schneider}

Table 5

Smallpox vaccination reported in west, central and east African colonies for selected years

\begin{tabular}{llcl}
\hline Year & $\begin{array}{l}\text { Reported } \\
\text { Vaccinations }\end{array}$ & $\begin{array}{l}\text { Total estimated } \\
\text { Vaccinations* }\end{array}$ & \multicolumn{1}{c}{ Data missing from } \\
\hline 1929 & $4,012,659$ & $5,875,950$ & Sierra Leone, Nigeria, Kenya, Uganda, AEF \\
1936 & $8,020,468$ & $8,020,468$ & \\
1946 & $14,123,121$ & $16,559,391$ & Kenya \\
1955 & $20,880,253$ & $25,820,504$ & Sierra Leone, Tanganyika, Uganda, \\
& & & N. Rhodesia, Belgian Congo \\
\hline
\end{tabular}

* Includes estimates for missing data based on average of closest three years reported.

colonies in west, central and east Africa examined in this study (French West Africa, French Equatorial Africa, Cameroon, Sierra Leone, Gold Coast, Nigeria, Kenya, Uganda, Tanganyika, Northern Rhodesia and the Belgian Congo) grew from an estimated $5,875,950$ in 1929 to $25,820,504$ in 1955 .

\section{Smallpox Treatment and Prevention}

How was smallpox treatment and prevention organized? The same basic tools were used that continued through the 1970s, which means that since there was no cure for the disease, the response consisted of screening and isolation of victims, and vaccination for prevention. Some graphic descriptions remain of measures taken, such as the following from a British doctor who served in Uganda from 1928 to 1948 and recalled when smallpox cases appeared in 1944, "[I]mmediate preparations were made to deal with an impending epidemic. These included the construction of a temporary hospital on a carefully selected site on a promontory at Port Bell within a few miles of Kampala and well removed from human habitation." 26

A nurse in Ibadan, Nigeria, described emergency vaccination steps taken during the 1957 epidemic there:

We set up vaccination stalls in the market, the zoo, the airport, the railway station and along every road into Ibadan and manned them whenever we were off duty for 24 hours a day, for a fortnight. Nobody was allowed into or out of the city without being vaccinated and the mammie wagons were emptied at the side of the road to ensure this. Student nurses were enlisted to go into the Hausa area to vaccinate the women who would not accept the male sanitation officers. It is reckoned we treated 100,000 people. Eventually, once they realized it did not hurt, many people turned up daily, and we had to paint their wrists with gentian violet to distinguish those who had been immunized or they would have been vaccinated on both arms and both legs. The teams consisted of a doctor or nurse who vaccinated, an unqualified wife or secretary, etc. who cleaned the area, and someone to control the crowd. The epidemic made all the natives realize the importance of regular immunization. ${ }^{27}$

\footnotetext{
${ }^{26}$ Oxford Rhodes Library, Mss Afr s1872, Raymond E Barrett.
}

\footnotetext{
${ }^{27}$ Oxford Rhodes Library, Mss Afr s 1872, Phyllis Dietl.
} 


\section{Smallpox in Africa during Colonial Rule}

Despite these efforts, she recounted, there were 1,000 cases of smallpox and over 500 deaths in the epidemic.

The smallpox vaccinations were extensive and began early. Systematic statistics for African colonies are difficult to find before the 1920s, but there are a number of reports from enough colonies that indicate colonial rulers introduced vaccination quickly, following the experience back in the home country. Moreover, since variolation (arm to arm) was widespread in traditional African societies, especially in the west, east and south, Africans were familiar with the disease and the idea of prevention.

Statistics for French African colonies began to be kept shortly after the mandatory French vaccination law was extended to the colonies in 1904, and over a million vaccinations were reported annually by 1911 in French West Africa. ${ }^{28}$ Like the overall report of cases, however, it is difficult to assess the effect of the vaccinations. Annual colonial medical reports indicate that increased vaccinations were an important response to an outbreak of smallpox; but so too was a call for stepped up regular vaccination.

The number and variations of cases and vaccinations for individual colonies within French West Africa were too great to draw any conclusions about connections (Figure 9), but the graphs for specific colonies are more helpful in describing the relationship (Figures 10 and 12 to 16). For example, some of the spikes in cases (sharp rise and quick decline) are likely explained by the rise in vaccinations during and after outbreaks of smallpox. There are less complete statistics for French Equatorial Africa, and the order of magnitude, except for Chad, is much smaller than for French West Africa. The number of smallpox cases in Gabon, French Congo and Oubangui-Chari (Central African Republic) was never more than a few dozen, figures that were far overshadowed when epidemics of thousands of cases hit Chad. It is not surprising that vaccinations in Gabon only exceeded 100, 000 in 1947, although Oubangui which bordered Chad, had closer to 200, 000 or more vaccinations beginning during the Second World War. More complete figures for cases and vaccinations are available for Chad as well as the large mandate territory of Cameroon. ${ }^{29}$ In both colonies, the epidemics were infrequent and presumably managed well by vaccination and isolation (Figures 11 and 17).

In the British colonies, the data are uneven, but the pattern of correlation between cases and vaccinations can be seen in the graphs in the Appendix. Vaccinations in Sierra Leone, Uganda, and Tanganyika appear to follow closely the rise and fall of smallpox cases, suggesting that vaccinations were a response to epidemics (Figures 2, 5, 7). The Gold Coast is of interest because data is good, but the pattern is not clear (Figure 3). Data for vaccinations in Kenya are incomplete, whereas, the numbers for Nigeria are so large that regional analysis is necessary (Figures 4 and 8).

The variations within Nigeria can be seen from Table 6 which shows that cases reported during the mid-1930s indicate a much higher prevalence of smallpox in the Northern provinces. Figures from fifteen years later, however, show a high prevalence

\footnotetext{
${ }^{29}$ Chad population estimate for 1958: 2,579,600;
} p. 42.

${ }^{28}$ AOF, 'Rapport, 1953', op. cit., note 8 above, Cameroon 2,230,000 in 1926, and 5,426,00 in 1957, 


\section{William H Schneider}

Table 6

Nigeria: cases and vaccinations by region, 1935-37

\begin{tabular}{|c|c|c|c|c|c|c|}
\hline \multirow[b]{2}{*}{ Year } & \multicolumn{2}{|c|}{ Northern } & \multicolumn{2}{|c|}{ Southern } & \multicolumn{2}{|c|}{ Lagos } \\
\hline & Cases & Deaths & Cases & Deaths & Cases & Deaths \\
\hline 1935 & 5,061 & 1,345 & 411 & 57 & 26 & 1 \\
\hline 1936 & 4,352 & 556 & 514 & 53 & 17 & 2 \\
\hline 1937 & 3,095 & 439 & 564 & 88 & 16 & 0 \\
\hline 1937 vaccinations & \multicolumn{2}{|c|}{477,862} & \multicolumn{2}{|c|}{393,324} & \multicolumn{2}{|c|}{38,336} \\
\hline
\end{tabular}

Source: Nigeria, Annual report on the medical services for the year 1937, Lagos, Government Press, 1937, p. 15.

Table 7

Nigeria: cases and vaccinations by region, $1947-51$

\begin{tabular}{|c|c|c|c|c|c|c|}
\hline \multirow[t]{2}{*}{ Year } & \multicolumn{2}{|c|}{ Northern (population $16.8 \mathrm{~m}$ ) } & \multicolumn{2}{|c|}{ Eastern (population $7.4 \mathrm{~m}$ ) } & \multicolumn{2}{|c|}{ Western (population $5.4 \mathrm{~m}$ ) } \\
\hline & Cases & Deaths & Cases & Deaths & Cases & Deaths \\
\hline 1947 & 4,370 & 860 & 563 & 23 & 492 & 71 \\
\hline 1948 & 3,519 & 516 & 1,868 & 287 & 357 & 27 \\
\hline 1949 & 5,542 & 771 & 6,251 & 981 & 3,070 & 494 \\
\hline 1950 & 10,036 & 1,928 & 7,254 & 953 & 3,650 & 493 \\
\hline 1951 & 8,101 & 1,632 & 2,498 & 432 & 1,280 & 212 \\
\hline \multicolumn{7}{|l|}{1951} \\
\hline vaccinations & \multicolumn{2}{|c|}{$1,552,986$} & \multicolumn{2}{|c|}{784,554} & \multicolumn{2}{|c|}{898,443} \\
\hline
\end{tabular}

Source: Nigeria, Annual report on the medical services for the year 1951, Lagos, Government Press, 1951, pp. 1618.

Table 8

Reports of vaccination rates in French West Africa and Nigeria, 1937 and 1951

\begin{tabular}{lllrc}
\hline Year & Colony & Population (estimated) & Vaccinations & Vacc/hab. \\
\hline 1937 & Fr. West Africa & 15.5 million & $2,435,471$ & 0.157 \\
1937 & N. Nigeria & 11 million & 477,862 & 0.043 \\
1951 & Fr. West Africa & 20 million & $5,267,049$ & 0.263 \\
1951 & Nigeria (all) & 30 million & $3,235,983$ & 0.108
\end{tabular}

in all regions (note: Southern now reported as Western and Eastern Regions) during this most serious epidemic of smallpox in any African colony during the twentieth century.

Even though the number of vaccinations in Nigeria was large, the population of the colony was even larger, hence the rate of vaccinations was lower overall compared to 


\section{Smallpox in Africa during Colonial Rule}

French West Africa. In 1937, for example, the rate in the French colonies was over 3.5 times that of Northern Nigeria, and by 1951, although both colonies increased, the French rate was still almost 2.5 times higher.

A chart of smallpox cases and vaccinations reported in the Belgian Congo, shows a rise of both cases and vaccinations. The colony was so large and the numbers so big, however, that, like Nigeria, it would require analysis at a smaller regional level to understand the relationship between vaccinations and prevalence (Figure 18). ${ }^{30}$

\section{Smallpox and Colonial Public Health: Between Service and Campaign}

The goal of medical officers in African colonies was control if not elimination of smallpox. This was similar to the situation in Europe where eradication was achieved in most countries during the first half of the twentieth century using well-known and effective practices based on a regular public health service model of vaccination and surveillance. ${ }^{31}$ The goal of mandatory vaccination legislation (1904 for French colonies; 1891 in Mozambique; 1920 in the Gold Coast) and the means were the same: reporting and isolation of cases, vaccination of infants, and periodic revaccination thereafter. African vaccinators were trained under European colonial medical officers. Vaccine was either imported or, increasingly, locally produced. Then, depending on local conditions and resources, vaccinations took place in towns and cities, or rural villages, in schools and clinics, and by visiting teams.

Although this mandatory, periodic service model was the most common means to achieve the goal of the laws, a campaign model also developed alongside it for at least two reasons. The first was to make an initial reduction in prevalence with inoculations as quickly and widespread as possible. In addition, vaccination campaigns were also a response to outbreaks of epidemics. As time went on, and epidemics continued and even increased, they became the primary reason for vaccinations, although each epidemic usually brought a call for stepped up, regular vaccination service.

To a certain extent the awareness of increased epidemics may ironically have resulted from better health service in the colonies that reached increasing numbers of people. As health officers, both European and African, grew in number and Africans came to use them more, there was a better means of identifying and reporting illnesses such as smallpox. Moreover, in the aftermath of each new outbreak there was more sensitivity, vigilance and attention paid to smallpox. In hindsight, however, the statistics also reflected the increased size of African populations and the greater movement of people which increased the chances of spreading disease.

There is insufficient space for extensive analysis of the effectiveness of the measures taken against smallpox in all of colonial Africa. The extent and persistence of reported cases are clear from the charts presented earlier. It is also clear that these measures controlled smallpox, even if they did not succeed in eliminating the disease or preventing

\footnotetext{
${ }^{30}$ Unfortunately, those figures were not available for this study.

${ }^{31}$ See Fenner, et al., op. cit., note 2 above, pp. 317-27. Eradication was relatively recent for the
}

colonial powers. According to Fenner, et al., p. 318, the dates for the last case of endemic smallpox in these countries were: Belgium: 1926; UK: 1934; France: 1936; and Portugal: 1953. 


\section{William H Schneider}

serious epidemics as late as the 1960s. In hindsight and on a broad level, smallpox was not eliminated during colonial rule because developments facilitating the spread of the disease — such as population growth and movement-outpaced efforts at monitoring, isolation, and prevention through vaccination.

It is of interest to examine how the reports of colonial medical departments described and explained the persistence of smallpox in the face of the considerable efforts to eliminate it. The reports varied greatly depending on the colonial power, the colony and even the conditions in different parts of a given colony. None the less, a handful of questions and problems were consistently raised in the records and reports of health services from the 1920s to the end of colonial rule in Africa.

One question often asked in colonial health reports, especially in colonies where smallpox was under control, was the origin of new outbreaks of the disease. The answer was usually that it was imported into the colony from outside. This could come in one of two ways. First there were traditional overland travel patterns, for example trade and pilgrimage routes across the Sahara, which continued after colonial boundaries were drawn. In addition, new disease patterns followed new routes made possible by investments in colonial transportation, especially railways and seaports, early in colonial rule. ${ }^{32}$ This can be seen in a series of smallpox outbreaks in the period before 1920, including an epidemic in 1913-14 that followed the Dakar-St Louis Senegal railway line, an epidemic in 1909 on the new Tanganyika railway line, and even earlier (1890) an outbreak along the construction route of the Matadi-Stanley Pool railway in Congo. The ports of Dar es Salaam and Zanzibar also recorded smallpox epidemics before the First World War. ${ }^{33}$

This question was especially important in colonies where little or no smallpox had previously been reported, such as Kenya and Uganda in the 1930s. As the 1934 annual report of the Kenya Medical Department noted, after three years of no incidents and sixteen years since anything like an epidemic (as occurred at the end of the First World War), a smallpox epidemic broke out "among certain Somalis in the northern frontier district", herders crossing the border. In all there were 1,781 cases and 645 deaths that year. "Hospitalization was out of the question", the report went on, and vaccinations were given so as to establish "a barrier of vaccinated people between the infected areas and the closely populated highland and lake districts". These began, according to the report, within three days and eventually totalled over 408,000 vaccinations which successfully confined the outbreak. Some vaccine was sent by air, taking hours as opposed to weeks by surface transport. The report boasted, "[F]ortunately in 1934 it was possible, as it was not in 1916-18, to ensure that the disease did not spread into any of the densely populated areas." 34

When smallpox appeared in Uganda the following year for the first time in many years, the annual report attributed it to visitors from India and a pilgrim returning from Mecca. ${ }^{35}$ Earlier, Tanganyikan authorities attributed an outbreak in 1930 to a passenger

\footnotetext{
${ }^{32}$ Hopkins, op. cit., note 2 above, pp. 196-7.

${ }^{33}$ Ibid.

${ }^{34}$ Kenya Medical Department, Annual medical report 1934, Nairobi, Medical Department, 1934, pp. 11-12 (hereafter Kenya, Annual medical report, with relevant date). In 1935 the number of cases of
} 


\section{Smallpox in Africa during Colonial Rule}

from Bombay, and a later report of a smallpox epidemic in 1943 concluded that it was introduced from the northern border. During that same year, Kenya reported a dramatic rise in smallpox cases (over 3,000), the first since the epidemic of the previous decade died out in $1937 .^{36}$

It is difficult to say where the major smallpox epidemics began that hit West Africa in the 1930s, in part because the new colonial boundaries cut across populations and trade routes resulting in very significant movement between the colonies. After the Second World War, there were finally some co-operative vaccination campaigns, such as in 1948 along the Gold Coast-Togo border. ${ }^{37}$ Two years earlier, the Nigerian authorities reported on an epidemic that hit the Northern provinces severely and noted, "[M]ass vaccinations in the Cameroon areas in 1945 seem to have had a beneficial effect as evidenced by the smaller number of cases reported there during the year under review." Smallpox in Sierra Leone was often reported as coming from the neighbouring French colony of Guinea. ${ }^{38}$

Nowhere were the unfortunate consequences of colonial boundaries being ignored by disease more evident than in Chad. Geographically, the colony was administered by the French as part of their "equatorial" federation, reflecting how the French arrived there moving north from Gabon, the middle Congo, and the Ubangui-Chari rivers. These latter colonies remained virtually free from smallpox in the 1920s and 1930s, with all except Chad having no more than a few dozen cases reported in any year, and some colonies like Gabon reporting no cases. French Equatorial Africa moved early to use only dried smallpox vaccine, proven to be more stable in hot climates than the locally produced lymph. Dried vaccine also avoided the problem of keeping livestock for vaccine production in a tsetse fly zone. ${ }^{39}$

Viewed from Brazzaville or Paris, this was a cause for self-congratulation, especially compared to the experience in French West Africa, which reported a total of 18,602 cases of smallpox from 1931 to 1938, compared to 1,201 in Equatorial Africa. All but 134 of the latter were in Chad and 842 of them were in the epidemic of $1938 .{ }^{40}$ A special report by the new Vichy government on "Health efforts in French Equatorial Africa" in March of 1941, described the source and response to the 1938 epidemic in Chad, which shows the limits of artificial administrative boundaries in the face of natural geographic forces.

The origin of the smallpox epidemic, according to the report, was in the region of Bol, on Lake Chad, on the southern edge of the Sahara and in the north-west of the inhabited

\footnotetext{
${ }^{36}$ Tanganyika Territory, Annual medical and sanitary report, 1930, Dar es Salaam, 1930, p. 8 (hereafter Tanganyika, Annual medical report, with relevant date); ibid., 1943, pp. 9-10; Kenya, Annual medical report, 1943, p.4; Conacher, op. cit., note 9 above, pp. 157-81, compiled a list of "extra-territorial sources of infection" in Tanganyika with seven incidents reported from 1925 to 1944 .

${ }^{37}$ Gold Coast, Report, 1948, pp. 6-7.

${ }^{38}$ Nigeria, Annual report on the medical services for the year 1946, Lagos, Government Press, 1946, p. 10 (hereafter Nigeria, Annual report, with relevant
}

date); Donald R Hopkins, J M Lane, E C Cummings, and J D Millar, 'Smallpox in Sierra Leone. I.

Epidemiology', Am. J. Trop. Med. Hyg., 1971, 20 (5): 689-96, p. 691.

${ }^{39}$ IMTSSA Box 81. Etat Français. Secretariat d'Etat aux Colonies. Direction du Service de Santé des Colonies, 'L'oeuvre sanitaire de la France en Afrique Equatoriale', 8 Mar. 1941 [following note of 10 Oct. 1940] partie médicale, "lutte contre variole", p. 18.

${ }^{40}$ Ibid., pp. 19-20. 


\section{William H Schneider}

part of Chad. It was described as "a region very difficult to monitor and where the inhabitants, generally nomadic, avoid vaccination and thus represent a veritable danger for neighbouring populations". In addition to the pastoral Fulani who ignored the Nigerian border to the west, there were Hausa merchants and pilgrims who moved from Nigeria to Mecca and regions to the east. ${ }^{41}$ Once colonial health authorities recognized the outbreak, they reacted like authorities in Kenya during the epidemic in the early 1930s, by setting up a quarantine line at Abeché, the largest regional centre east of the capital which was on the route to the Anglo-Egyptian Sudan. In the words of the report, "vaccinations numbering 8,441 for a normal population of 6,500 inhabitants stopped any further spread of the epidemic". Reports for the following years, however, show even more cases $(1,206)$, and the epidemic did not subside until after the Second World War. $^{42}$

\section{African Resistance to Vaccination}

Outbreaks of smallpox, as well as its persistence, were also frequently explained in colonial health reports as being the result of resistance by Africans to being vaccinated. This was especially the case in the early years of systematic vaccination beginning in the 1920s, although such accusations were telling in their lack of detail. Thus the 1933 medical report for Sierra Leone, complained, "Fear of vaccination also accounts for the fact that only 57,141 vaccinations could be performed in the infected areas." When the epidemic continued the following year, the medical authorities admitted, "It is expected that the disease will now soon burn itself out, and that the normal annual vaccinations performed will serve to prevent all but sporadic cases which will continue to occur in the more remote districts, or in those areas where people flee from vaccination." 43

French officials occasionally complained of resistance by Africans to vaccination in the late 1920s and early 1930s, although only in vague terms. Thus the official report on vaccination to the French Academy of Medicine in 1933 stated that, for African colonies in 1931, "the numbers of those not vaccinated remains high, especially among infants as a result of the hostile propaganda of witch doctors [féticheurs]". ${ }^{4}$

The traditional practice of variolation was also blamed for some cases of smallpox. This was less because of resistance to vaccination than the persistence of this earlier method of inoculation. For example, a 1926 report from the French colony of Upper Volta indicated there was surprise at the increased number of smallpox cases and deaths that year. After inquiries were made, the problem was found in more than one district to be the result of the traditional practice of variolation.

\footnotetext{
${ }^{41}$ Ibid., p. 29.

${ }^{42}$ Ibid. There were 1,670 cases in 1945; 243 in 1946; and 41 in 1947.

${ }^{43}$ Sierra Leone, Annual report of the Medical and Sanitary Department. 1933, Freetown, Sierra Leone, 1933, p. 37; ibid., 1934, p. 33.

${ }^{44}$ Lucien Camus, 'Rapport général annuel sur les vaccinations et revaccinations pratiquées en France pendant l'année 1931', Bulletin de l'Académie de Médecine, 1933, 110: 561-6, p. 564. For more on
}

French administrators' perceptions of how Africans understood Western medicine, see Kalala Ngulamulume, 'La question sanitaire durant les prémières années de l'AOF, 1895-1914', in Becker, et al. (eds), op. cit., note 16 above, pp. 1203-11. Danielle Domergue-Clouarec, 'Prévention dans la politique sanitaire de l'AOF', in ibid., pp. 1228-39, on p. 1238, cites early resistance to vaccinations by the population in Niger as motivated by avoiding the census for military and labour conscription. 


\section{Smallpox in Africa during Colonial Rule}

In the canton of Djibo (region of Ouagadougou) 4 cases of smallpox in two villages were the source of 83 variolations which were followed by 9 deaths. The village chief declared that each time a case of smallpox appeared, the whole population must be inoculated with smallpox pus. Djibo is entirely populated by Fulanis, a Moslem people who follow the variolation of the Arabs. ${ }^{45}$

In fact, there were as many, if not more, references in the health reports to how well the Africans accepted and even welcomed vaccination. For example, following an outbreak of smallpox in the Gold Coast in 1929, the colonial medical report stated, "A feature of the outbreak was the extraordinary manner in which the chiefs and people cried out for vaccination. This demand did not cease on the cessation of the epidemic and many areas are still demanding vaccination." 46 The following overly optimistic report accompanied the description of an epidemic in Northern Nigeria in 1936,

There is little doubt that opposition to vaccination is fast disappearing. Little or no difficulty is now experienced in persuading Native Authorities in Northern Nigeria to introduce compulsory vaccination of children (which already pertains for all persons in Southern Nigeria) and advantage is taken of this to offer protection to mothers and adults generally. In time, it is hoped that compulsory vaccination will be extended to all persons in the Northern part of the Protectorate which receives large numbers of immigrants from neighbouring territories. ${ }^{47}$

In the post-war years smallpox epidemics not only increased in Nigeria but spread to the south and west where administrators had earlier prided themselves on the thoroughness of vaccinations. A 1948 outbreak in the Western provinces of Benin-Warri was partly blamed on Africans as follows, "Concealment of and refusal to isolate cases together with apathy and even hostility to vaccination on the part of the population greatly impeded the work of the Health staff dealing with the outbreak." 48 By 1953, however, Nigerian health officials could no longer blame Africans, as smallpox continued at high levels, despite increased vaccinations which rose from 2,519,464 in 1947 to $3,699,298$ in 1953. As will be seen below, officials now turned to technical inadequacies for explanations, because, as the 1953 annual report stated, "active opposition to vaccination particularly by local vested interests such as a gerontocratic oligarchy of 'juju' priests, fetish men and witch doctors is, happily, a thing practically of the past" ${ }^{49}$

\section{Quality and Use of Vaccines}

The vaccination problems most frequently mentioned by colonial health authorities were technical in nature and almost always focused on two recurring difficulties: the potency of vaccines and the thoroughness of administration both in following procedures and reaching enough of the population. Health officials recognized very early that there was a problem of vaccines losing their effectiveness. As mentioned above, this was first reported by French doctors attempting vaccinations in the French Soudan in the 1904 and

\footnotetext{
${ }^{45}$ Lucien Camus, Rapport général par l'Académie de Médecine sur les vaccinations et revaccinations pratiquées en France, en Algérie et dans les pays de protectorat pendant l'année 1927, et aux colonies pendant l'année 1926, Paris, Masson, 1928, p. 61.
}

\footnotetext{
${ }^{46}$ Gold Coast, Report, 1929-30, p. 28.

${ }^{47}$ Nigeria Annual report, 1936, pp. 22-3.

${ }^{48}$ Ibid., 1948, p. 19.

${ }^{49}$ Ibid., 1953-54, pp. 26-7.
} 


\section{William H Schneider}

even earlier by the Portuguese in Mozambique during the last part of the nineteenth century when they tried to import vaccine from their colony in Goa (India). ${ }^{50}$ Similar observations by the British resulted in the establishment of local production of lymph vaccine in most colonies.

In French West Africa, vaccine was produced locally in Senegal at the capital of St Louis beginning in 1895. Attempts to transport this to the interior, however, soon showed how quickly the vaccine lost its effectiveness in hot climates. A medical corps Major accompanying an expedition to Timbuktu in 1904 failed to produce a single positive inoculation in 360 attempts. This problem was solved that same year by another medical officer in the interior region who inoculated livestock (calves and horses) to obtain fresh vaccine. With this supply he claimed, "I vaccinated eleven to twelve hundred people both at Timbuktu and Kabara. For infants not yet exposed to smallpox, I had a [positive] percentage of 85 to $90 \%$." 51

A vaccine production facility was established at the Pasteur Institute in Kindia, Guinea, in 1905 shortly after the French law of 14 April 1904 was passed requiring vaccination. This permitted 18,392 vaccinations in the colony that year. In 1909 Kindia also began producing a more stable dried vaccine with positive results reported in 71 to 89 per cent of vaccinations. ${ }^{52}$ In the meantime, a 1905 report from a medical inspector for colonial health recommended that the French establish local vaccine production at key interior locations in the West African colonies because of the problem of transporting fresh vaccine. ${ }^{53}$ By 1927, in addition to the production facilities in Senegal and Guinea, the French Soudan had them in the capital Bamako (601,000 doses produced in 1926) as well as four secondary centres in more remote areas including Timbuktu (56,618 doses in 1926). In Upper Volta, vaccine was produced in the capital Ouagadougou and two other centres (Bobo-Dioulasso and Dedougou). Vaccine in that colony was sent by bicycle at night to as far away as $150 \mathrm{~km}$ to retain effectiveness. The more stable and costly dry vaccine was used for sites further away. In Niger fresh vaccine was produced in the capital Niamey and three regional centres (Zinder, Tahoua, and N'Guigmi). Dry vaccine from Paris was used in the desert centres of Bilma and Agadez in the north. In Cameroon the port city of Douala produced vaccine in the 1920s for all the French mandate territory except the north where dry vaccine was used. ${ }^{54}$

In Mozambique, attempts at importing seed vaccine from Goa and Lisbon were unsuccessful until the end of the nineteenth century. Only after a severe epidemic in 1918, likely prompted by troop movement at the end of the war, which resulted in

${ }^{50}$ AOF, 'Rapport, 1953', op. cit., note 8 above, pp. 37-8; IMTSSA Box 431, folder 'Variole, notes pour P. Richet ...'; Cardoso de Andrade, 'La variole au Mozambique', working document for WHO conference of eradication of smallpox in Africa, 15 Nov. 1959, pp. 2-3.

${ }^{51}$ AOF, 'Rapport, 1953', op. cit., note 8 above, pp. 37-8.

${ }^{52} \mathrm{~J}$ G Breman, A B Alécaut, and J M Lane, 'Smallpox in the Republic of Guinea, West Africa, Part 1: History and epidemiology', Am. J. Trop. Med. Hyg., 1977, 26: 756-64, p. 757; R Fasquelle and A
Fasquelle, 'A propos de l'histoire de la lutte contre la variole dans les pays d'Afrique francophone', Bulletin de la Société de Pathologie exotique, 1971, 64: 734-54, p. 741.

${ }^{53}$ AOF, 'Rapport, 1953', op. cit., note 8 above, pp. $39-40$.

${ }^{54}$ Camus, op. cit., note 45 above, p. 61; Lucien Camus, 'Rapport général annuel sur les vaccinations et revaccinations pratiquées en France pendant l'année 1927', Bulletin de l'Académie de Médecine, 1929, 102: 471-4. 


\section{Smallpox in Africa during Colonial Rule}

Table 9

French West and Equatorial Africa smallpox vaccine production, 1931

\begin{tabular}{|c|c|c|}
\hline Colony & Locations & Notes \\
\hline Senegal & Saint-Louis & For all of Senegal and Mauretania. \\
\hline French Soudan & Bamako +4 centres & \\
\hline Upper Volta & 2 centres & \\
\hline Niger & 7 centres & All closed in March 1931; replaced by dry vaccine. \\
\hline Guinea & Kindia (Pasteur Inst.) & Also produced dry vaccine. \\
\hline Ivory Coast & Bouake' & $\begin{array}{l}\text { Closed end of } 1931 \text { and replaced by dry } \\
\text { vaccine from Paris and fresh vaccine from } \\
\text { Upper Volta. }\end{array}$ \\
\hline Dahomey & Abomey +2 centres & More dry vaccine used (78\%) than fresh. \\
\hline Cameroon & N'Gaoundére' & Replaced centre at Douala in July 1931. \\
\hline French Equatorial & & Only dry vaccine from Paris used. \\
\hline
\end{tabular}

Source: Lucien Camus, 'Rapport général annuel sur les vaccinations et revaccinations pratiquées en France pendant l'année 1931', Bulletin de l'Académie de Médecine, 1933, 110: 561-6.

over a thousand cases of smallpox, did the colonial health authorities establish a production facility in Lourenço Marques (now Maputo) which was able to supply the whole colony by 1920 . Tests showed it produced a 60 per cent success rate of vaccination. ${ }^{55}$

Khartoum produced vaccine locally for the Anglo-Egyptian Sudan beginning only in 1937, although dried vaccine imported from Paris after 1930 helped cut the smallpox rate in the more remote Darfur region. ${ }^{56}$ In Nigeria a lymph vaccine was produced locally at Vom in the north, but it was stopped in 1937 because of contamination. Vaccine was imported from the Lister Institute in Britain, until production at the Yaba Laboratory outside Lagos was sufficient to meet needs. It produced over 5 million doses of vaccine by 1950. Nairobi produced vaccine for Kenya and other British colonies in East Africa. ${ }^{57}$

Even with local production of vaccine in Africa, in the face of repeated epidemics, the debate continued about loss of effectiveness due to heat and transportation to remote locations. Although the standard test for smallpox vaccine effectiveness in European laboratories was on rabbits, the more practical and common reference in Africa was a return visit to those recently vaccinated. If after about eight days a scar was formed where the vaccination occurred, it was considered positive. Every colony reported figures for positive rates of those they were able to track down for verification. The figures varied so much, however, that their accuracy is highly suspect and they are thus more useful in revealing health authorities' reaction to them than for monitoring the actual effectiveness of procedures. For example, in the Gold Coast, success rates were

\footnotetext{
${ }_{56}^{55}$ Andrade, op. cit., note 50 above, p. 3.

${ }^{56}$ A Bayoumi, 'Smallpox in the Sudan, 1925-1964', East Afr. Med. J., 1974, 51 (1): 131-40, p. 135. For an even more extensive case study of Sudan, see Gerald W Hartwig, 'Smallpox in the Sudan', Int. J. Afr. Hist. Stud., 1981, 14 (1): 5-33.
}

\footnotetext{
${ }^{57}$ Kenya, Annual medical report, 1950, p. 20; Tanganyika, Annual medical report, 1951, p. 46; Nigeria, Annual report, 1937, p. 15; 1941, p. 7; 1956, p. 28. The first production reports from Yaba appear in the 1941 Nigerian medical report.
} 


\section{William H Schneider}

low initially (1928-29: 27.7 per cent, 1930-31: 18.8 per cent), but then jumped in 1931-32 to 87.6 per cent and stayed that high the rest of the decade, with no explanation or even comment. ${ }^{58}$ As mentioned above, the Portuguese were content with a 60 per cent success rate, perhaps because cases of smallpox were low in number.

A 1941 report on health in French Equatorial Africa for the new Vichy government indicated a success rate of 69.6 per cent for vaccinations between 1935 and 1937, and 34 per cent for revaccinations. This was using only dried vaccine. Comparable statistics in French West Africa were 80 per cent for vaccinations and 58 per cent for revaccinations, using much less dried vaccine. No comment was given either as explanation or conclusions to be drawn. ${ }^{59}$ The French Soudan reported a success rate of 73.7 per cent in 1931 using a combination of fresh and dried vaccine, but four years later the same colony reported only a 37.9 per cent positive rate for vaccinations. The annual medical report for the colony explained this dramatic change with another variation of blame on Africans and their training. "This low percentage is attributable not to the nature of the vaccine used (the fresh vaccine is produced and transported under the best conditions possible), but to the numerous technical errors often committed by inadequately trained nurse vaccinators." 60

Before turning to this question of administration, a few words need to be said about a continuing debate over the effectiveness of fresh versus dried vaccine. This is especially important, because one of the reasons commonly offered for the success of the WHO eradication campaign was its use of dried vaccine which could be stored indefinitely. ${ }^{61}$ In fact, an effective and practical technique for drying smallpox vaccine was discovered at the end of the nineteenth century. Using evaporation in a vacuum over a sulphuric acid bath, Robert Wurtz at the French Vaccine Institute on rue Ballu in Paris prepared vaccine for an expedition to Ethiopia in 1894. The vaccine kept its potency after the voyage and was used to inoculate calves which reportedly enabled vaccination for over 250,000 people. Wurtz's student Lucien Camus developed an improved early freeze-drying technique which prepared vaccine in large quantities that were used in 1909 in Guinea with a success rate between 71 and 89 per cent. ${ }^{62}$ The Portuguese used a dried vaccine from Germany.

In subsequent tests, there was little doubt that the dried vaccine gave success rates close to those of fresh vaccine in the laboratory and higher rates in the tropics because heat did not diminish its effectiveness. The dried vaccine powder was mixed with glycerine in a sterile watch glass just prior to use, and the only problems reported were in mixing the powder thoroughly enough and trying to save unused vaccine for later

${ }^{58}$ Gold Coast, Reports, 1928-1934.

${ }^{59}$ IMTSSA Box 81 , 'L'oeuvre sanitaire', op. cit., note 39 above, p. 22. Though not recognized at the time, revaccination required a more potent vaccine to work. World Health Organization, WHO Expert Committee on Smallpox: first report, Technical Report Series No. 283, Geneva, World Health Organization, 1964, p. 18.

${ }^{60}$ Camus, op. cit., note 44 above, p. 562; Lucien Camus, 'Rapport général annuel sur les vaccinations et revaccinations pratiquées en France pendant l'année 1936', Bulletin de l'Académie de Médecine, 1937, 118: 714.

${ }^{61}$ On the history of vaccine production, in addition to Fenner, et al., op. cit., note 2 above, pp. 278-91, see Fasquelle and Fasquelle, op. cit., note 52 above, pp. 740-6, and L H Collier, 'The preservation of vaccinia virus', Bacteriol. Rev., 1954, 18 (1): 74-86.

${ }^{62}$ Wurtz, Semaine médicale, 7 Dec. 1898; Joyeux, CRSB, 1909, 67: 624, as cited in Fasquelle and Fasquelle, op. cit., note 52 above, pp. 740-1. 


\section{Smallpox in Africa during Colonial Rule}

inoculation. ${ }^{63}$ In fact, most tests showed little difference in effectiveness as long as the fresh vaccine was kept cool, so this really was a debate about implementation.

The fundamental question facing colonial administrators in Africa was whether the expense and effort of transporting and keeping fresh vaccine effective was greater than the cost of the dried vaccine which was about six times the price of fresh vaccine. Not surprisingly, different colonies responded in different ways. The French used dried vaccine earlier and more often than the British, Belgians or Portuguese. This was probably because of the geographical extent of their empire, as well as the early production facilities available in Paris and generally higher prevalence of smallpox especially in their West African colonies. As mentioned above, the authorities in French Equatorial Africa decided in the early 1930s to use only dried vaccine; whereas Senegal used only fresh vaccine produced in St Louis. There were other colonies in West Africa that used a combination, depending on the distances and time to be covered in transport. Notably, the British authorities, especially in Nigeria where smallpox was most endemic, were late in using dried vaccine. ${ }^{64}$

\section{Administering Vaccination}

The administration of vaccinations depended on the national and colonial policies as applied to specific settings in Africa. The focus of this paper is on the latter, that is the situation in the field, but it was obviously influenced by these broader policies and institutions. Thus, for example, France organized her sub-Saharan colonies into two larger regions: West and Equatorial Africa, the effect of which was to make local colonial practices more uniform, at least for regions. France also had a Pasteur Institute with local branches in a number of African colonies (for instance, Senegal and Guinea) which made modern medical expertise more readily available in the African setting. British colonies tended to be more isolated and independent, which was also the case with the Belgian Congo, a circumstance magnified by the size and diversity of the colony. There was some regional co-ordination in British east and southern African colonies, but less than one might expect, given the similarities and continuities of geography.

Geography also exercised an influence on the occurrence of smallpox and efforts to eliminate it. Most obvious was the movement of people both within and across borders in ways that defied control, given the scant colonial administrative resources. For example, one important traditional route transmitting smallpox was east and west across British and French colonies in the Sahel for movement of goods and the pilgrimage to

${ }^{63}$ IMTSSA 323, 'Vaccinations: règles générales', attached to a cover letter dated 14 Dec. 1945 from Director-General of Health, Provisional Government to all health directors of French armed forces and colonies, p. 6.

${ }^{64}$ In addition to the official reports (Camus, 1927, 1929, 1931, 1933, 1937), see Andrade, op. cit., note 50 above, p. 1, for use of German dried vaccine in Mozambique. As late as 1956 the Lagos laboratory was "experimenting" with dried smallpox vaccine. In 1959 , the laboratory reported production of 721,925 doses of freeze-dried production compared to over 13 million fresh lanolinated. Nigeria, Annual report, 1956, p. 28; 1959, p. 61. For Kenya, see N R E Fendall and J G Grounds, 'The incidence and epidemiology of disease in Kenya. II. Some important communicable diseases', J. Trop. Med. Hyg., 1965, 68: 113-20, pp. 114-15. Bayoumi, op. cit., note 56 above, p. 136, states that the Sudan only began freeze-dried production in 1957; and in Sierra Leone dried vaccine was first used in 1966 , according to Hopkins, et al., op. cit., note 38 above, p. 692. 


\section{William H Schneider}

Mecca. Likewise, the centuries-old trade connections from South Asian and East African ports continued (and even increased) after colonial rule, connecting Africa to the source of one of the highest endemic regions for smallpox. Other examples of the influence of geography were the heat and transportation difficulties which reduced the effectiveness of lymph vaccine to such a point that policies had to be adapted to the situation. Finally, population density in Nigeria and parts of other colonies influenced the epidemiology and control of smallpox.

The manner in which vaccination was done, both the technique and frequency, was the question perhaps most often discussed about smallpox during colonial rule in Africa. Part of this focused on when to revaccinate. Most colonies required vaccination in the first year of life, but the frequency of revaccination thereafter varied between colonies and also changed over time in the same colony. Thus, in France as in its colonies, the law of 1904 required vaccination in the first year with revaccination in the tenth and twentieth year of life. This was done in Equatorial Africa by dividing each medical region into ten districts and doing vaccinations in each district on a rotating basis. When mobile teams were created to do combined vaccinations for yellow fever and smallpox in West and Equatorial Africa, however, they did so every four years. ${ }^{65}$ In Cameroon a new vaccination requirement was initiated in 1932 which followed the AEF procedures but on a six-year cycle. ${ }^{66}$ In Mozambique the law of 1921 required vaccination in the first and seventh year, but this was changed to every three years. By the 1950s children were revaccinated every year when they returned to school. ${ }^{67}$

Long term, as epidemics continued to occur, the campaign model of mass vaccinations overshadowed the regular periodic vaccination programmes and made them difficult to monitor. Some evidence of this can be seen in the graphs in the Appendix of reports of smallpox plotted against vaccinations. In many colonies the vaccinations rose and fell with epidemics. ${ }^{68}$ The other long-term trend was the increasing realization by colonial health administrators, especially in West Africa, that there was something more fundamentally wrong with their efforts. By the 1950s reports began to admit that the problem was not contagious travellers or effectiveness of vaccines but reaching enough people and following procedures strictly enough for those vaccinated.

An examination of the views of administrators in the two places with the highest continuing incidence of smallpox-Nigeria and French West Africa-will illustrate this. The 1953 annual report of the health service in French West Africa included detailed analyses of three diseases in the colonies: plague, yellow fever and smallpox. The 25-page examination of smallpox in West Africa began with the observation, "If one considers that the entire population of the Federation has been vaccinated theoretically every four years since 1938, it is surprising that smallpox still exists at a high rate in A.O.F. [French West Africa]." ${ }^{69}$ The report then reviewed fifty years of records since the official

${ }^{65}$ IMTSSA 323, 'Vaccinations: règles générales', op. cit., note 63 above, p. 1; Fasquelle and Fasquelle, op. cit., note 52 above, p. 740; AOF, 'Rapport 1953', op. cit., note 8 above, p. 36 .

${ }^{66}$ IMTSSA, Box 81, 'L'oeuvre sanitaire', op. cit., note 39 above, p. 21; 'L'oeuvre sanitaire de la France au Cameroun', p. 8.

\footnotetext{
${ }^{67}$ Andrade, op. cit., note 50 above, p. 6.

${ }^{68}$ This was the conclusion of Bayoumi for the Sudan, op. cit., note 56 above, p. 139.

${ }^{69}$ AOF, 'Rapport, 1953', op. cit., note 8 above, pp. 35-59.
} 
declaration of mandatory vaccination in West Africa, "in order to clarify the problem raised by the persistence of this affliction".

The findings were presented in graphs of the cases of smallpox and deaths reported and the number of vaccinations. The most important conclusion of the study was "a persistence, and even a tendency of growth in the frequency of the disease despite intensive vaccinations and revaccinations". To underscore this, the French report cited the figure of 73 million vaccinations in the previous twenty years alone, based on the most reliable records. The report prompted the health service to examine three questions: the effectiveness of vaccines, the effectiveness of vaccination practice, and the validity of reporting of smallpox. ${ }^{70}$ These questions were studied in individual colonies, and an outside report commissioned from the director of the Pasteur Institute in Paris, Jacques Trefouel. ${ }^{71}$ Both Trefouel and the colonial studies validated the effectiveness of the dry and fresh vaccines, including the mixed yellow fever/smallpox vaccine used increasingly since the 1940s. In addition, Trefouel found little reason to question the reports of the smallpox epidemics.

Trefouel's report, as well as a directive the following year from Director-General Sanner of the Public Health Service for French West Africa, concentrated instead on the practice of vaccination. Specifically, Sanner pointed to the need "to reduce absenteeism; [and] to verify very closely the quality of vaccinations given". ${ }^{72}$ As examples, he instructed local authorities to keep close census figures on vaccinations, and for vaccination teams to work more slowly, paying particular attention to things such as tracking down those not vaccinated, keeping the vaccine in the best possible condition, and disposing of vaccine remaining after the sessions. Sanner also stressed the importance of giving better consideration to those vaccinated by following such practices as making sure they could wait in the shade both before vaccination and for ten minutes thereafter to check for reactions. The conclusion of the report underscored this shift of attention. "The practice of vaccination is certainly questionable and, after absenteeism, appears to be the factor most responsible for the persistence of the disease." Unfortunately, it concluded, "time is the only means to diminish the ransom being paid by the people", while awaiting this improvement in public health. ${ }^{73}$

At almost the same time, authorities in Nigeria arrived at similar conclusions. The 1951 annual medical report for the colony first noted that the epidemic of 1948-51 could actually have been the product of better record keeping, that is, it might, "possibly be due to better notification resulting from the widespread medical and administrative activity in rural areas which accompanied and followed recent outbreaks of cerebrospinal fever". The report also acknowledged, however, the influence of such things as geography,

\footnotetext{
${ }^{70}$ Ibid., p. 45.

${ }^{71}$ Trefouel to Direction of Health Service, Minister of Colonies, 20 Apr. 1954. IMTSSA 165, folder 'AOF, 1954-55, Variole'. p. 45.
}

\footnotetext{
${ }^{73}$ Ibid., pp. 46-8, pp. 51-2. The annual report the following year was no more encouraging, concluding there was no quick fix, other than better understanding by the population, which unfortunately was, "without a central order or civic sense." See AOF, 'Rapport, 1954', op. cit., note 18 above, p. 4.
} 


\title{
William H Schneider
}

climate and migration. After analysing the epidemiology of cases and deaths by region from 1947 to 1952, the report concluded,

There is a marked seasonal fluctuation in incidence in all regions, an increase in the dry season and a decrease during the rains. This is more marked in the North than elsewhere. The occurrence of considerable numbers of cases in the East and West during the rains of 1949 and 1950 indicates that increased humidity per se has little effect on the transmissibility of the virus. It is likely that the fluctuations are due to seasonal variations in the movements of population. During the rains there is far more coming and going in the East and West than in the North. In the North, during the short wet season, everyone is busy on his farm, many roads are closed, and distances are great. Conversely, in the dry season, the Northerner is a great traveller; bands of labourers from the remotest northern villages trek to seek work as far south as ports on the coast and Niger Delta. This suggests one method of approach to improved control—the vaccination of travellers on all the main traffic arteries. ${ }^{74}$

On a less optimistic note, the 1951 report went on to mention the technical difficulty of reliable vaccines and the problem with supervision of those doing vaccinations. The conclusion was sobering. "Real control lies in increasing the reliability and output of provincial and district staff, mostly Native Administration employees, who alone are in a position to vaccinate with sufficient frequency and regularity the population in their care." 75

The following year the incidence of smallpox declined to 29.7 cases per 100,000 throughout Nigeria, compared to 38.1 in 1951 and the high of 67.2 in 1950, but the report that year was frank in admitting, "It would be over sanguine to suppose that the recent reductions have been wholly due to the preventive measures taken or forecast that this trend will continue.,"76 The Medical Department annual report for 1953-54 began with a reminder, "vaccination against smallpox is one of the cheapest and most successful public health preventive measures that have yet been introduced into this or any other country". The responsibility for the failure to eliminate smallpox, it concluded, was in part, the result of an old problem, "difficulties of distributing lymph in such a way that it retains its potency". In addition, the report reiterated the fundamental problem raised in previous years that impeded effective public health work. "It is regrettable to have to record that this work is often not undertaken by all members of the health staff with the sense of duty and conscientiousness it deserves." This included fabricating excuses that played to European prejudices. "When enquiry is made as to why more vaccinations have not been carried out in the area, it is sometimes advanced as a reason by the vaccinator that the people are 'antagonistic' to the measure. The real reason is more likely to be his own inertia; and where antagonism does actually exist, it is often engendered by his own venality or tactless and aggressive approach.,"77 The report's conclusion expressed the frustration of health officials with the simple facts of how far things had progressed and yet how much remained to be done in Nigeria. "The problem of smallpox will not be solved until an efficient system for the distribution of potent lymph has been worked out, and until routine vaccinations of infants and young children is given topmost priority."

\footnotetext{
${ }^{74}$ Nigeria, Annual report, 1951, p. 17.

${ }^{75}$ Ibid., pp. 16-18.
}

\author{
${ }^{76}$ Ibid., 1952-53, pp. 38-9. \\ ${ }^{77}$ Ibid., 1953-54, pp. 26-7.
}




\section{Conclusion}

Fenner and his colleagues were bold and confident enough to have a concluding chapter in their magnum opus entitled 'Lessons and Benefits'. After an appropriate bow of modesty acknowledging that every disease has its own peculiarities which determine the possibility of eradication-in the case of smallpox the fact of an early discovery of a mechanism of prevention and the lack of an animal reservoir-they went on to offer an explanation of why in the case of smallpox they were successful, whereas others before had failed.

Their first point was the importance of worldwide co-operation, but this was for marshalling sufficient resources as well as co-ordinating detection and quarantine. Also important, however, were the technological developments of a vaccine (freeze-dried) that kept its effectiveness even in tropical climates, and the adoption of a simple, bifurcated needle for vaccination. These, they suggested, were the main keys to success in West and Central Africa, at least, where only two years after the beginning of the programme in 1967, they had virtually eliminated smallpox. Moreover, this was the region where smallpox had remained endemic despite campaigns against it since the beginning of the twentieth century. ${ }^{78} \mathrm{~W} \mathrm{H}$ Foege, in a reconsideration of the West African success thirty years later, however, was much more honest in admitting, "in retrospect it seems clear-we didn't know how to eradicate smallpox when we started". He was explicitly referring to the non-technical but crucial "surveillance-containment" strategy. ${ }^{79}$

A close examination of the record of earlier campaigns during colonial rule agrees with Foege and questions the over-emphasis by Fenner and his co-authors on the role of new organizational and technical developments. After all, smallpox was eliminated with the older technology in other regions, including places in Africa such as Madagascar, and for a while, Kenya and the Ivory Coast. The lesson from the campaigns against smallpox would appear to be that simply employing more effective techniques to solve a problem may not ensure a solution if it continues in the same context. Rather the success was the result of training and the establishment of an infrastructure to monitor completely, and ensure procedures were followed as required. This enabled authorities to reach the entire population, identify and isolate new cases of smallpox, and prevent the introduction of new ones in areas where it had been eliminated. Health authorities achieved this in some colonies, but the resources and commitment to do it did not exist everywhere in Sub-Saharan Africa. It took the combination of co-operation at the international level plus newly independent African governments willing to try a new system of vaccination, for smallpox finally to be eradicated.

\footnotetext{
${ }^{78}$ Fenner, et al., op. cit., note 2 above, pp. 1349-63.

${ }^{79}$ W H Foege, 'Commentary: smallpox eradication in West and Central Africa
} revisited', Bull. World Health Organ., 1998, 76 (3): $233-5$. 
William H Schneider

Appendix

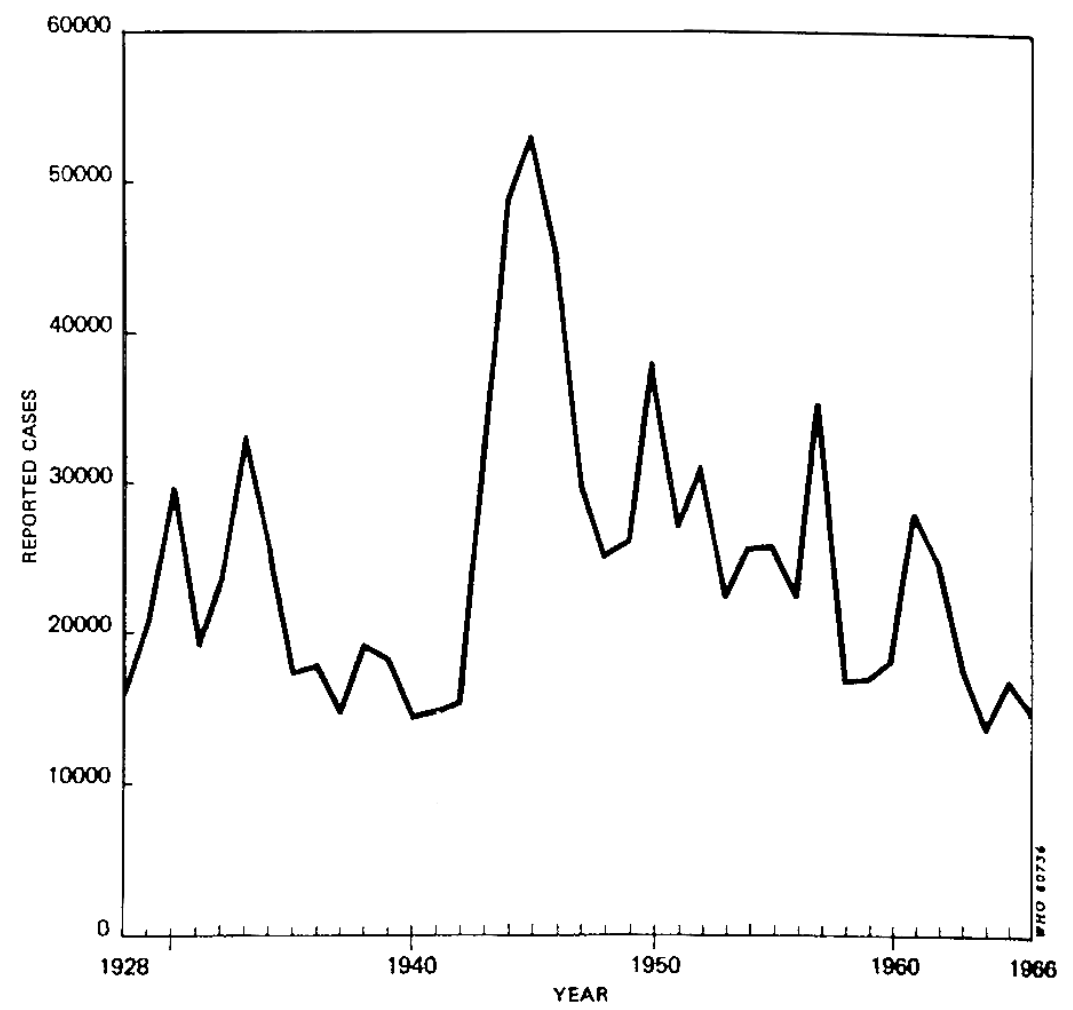

Figure 1: Reported smallpox cases in Africa, 1928-66.

Source: J L Tulloch, 'The last 50 years of smallpox in Africa', WHO Chronicle, 1980, 34 (11): 407-12, p. 408. 
Smallpox in Africa during Colonial Rule

Smallpox cases and vaccinations, Sierra Leone, 1931-58

(population 1,768,480 in 1932; 2,241,000 in 1960)

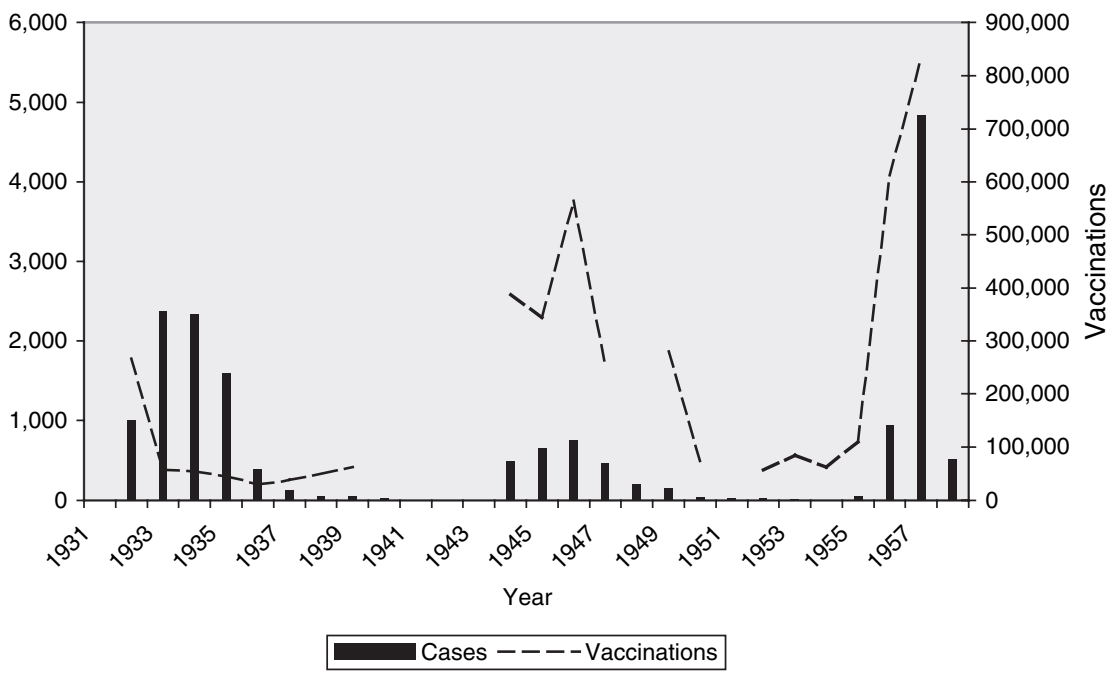

Figure 2

Smallpox cases and vaccinations, Gold Coast, 1927-58

(population: 3,357,950 in 1933; 4,670,000 in 1955)

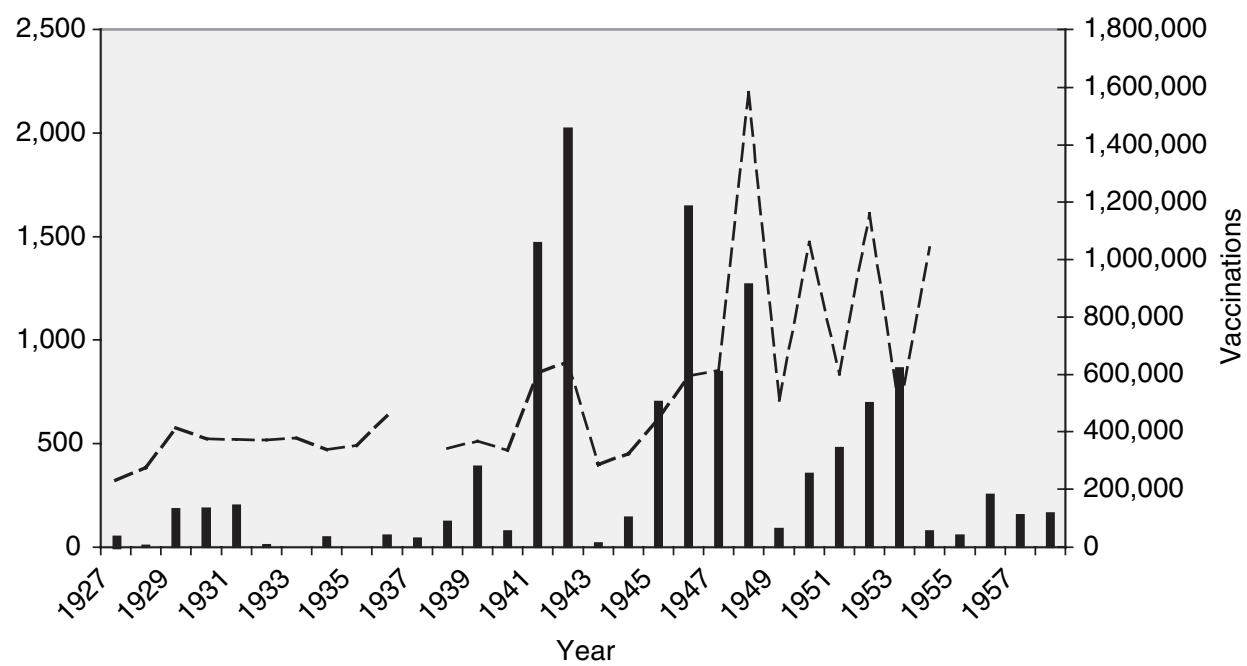

Cases - - - Vaccinations

Figure 3 


\section{William H Schneider}

Smallpox cases and vaccinations, Kenya, 1930-60 (population: $3,024,975$ in $1934 ; 6,081,000$ in 1959)

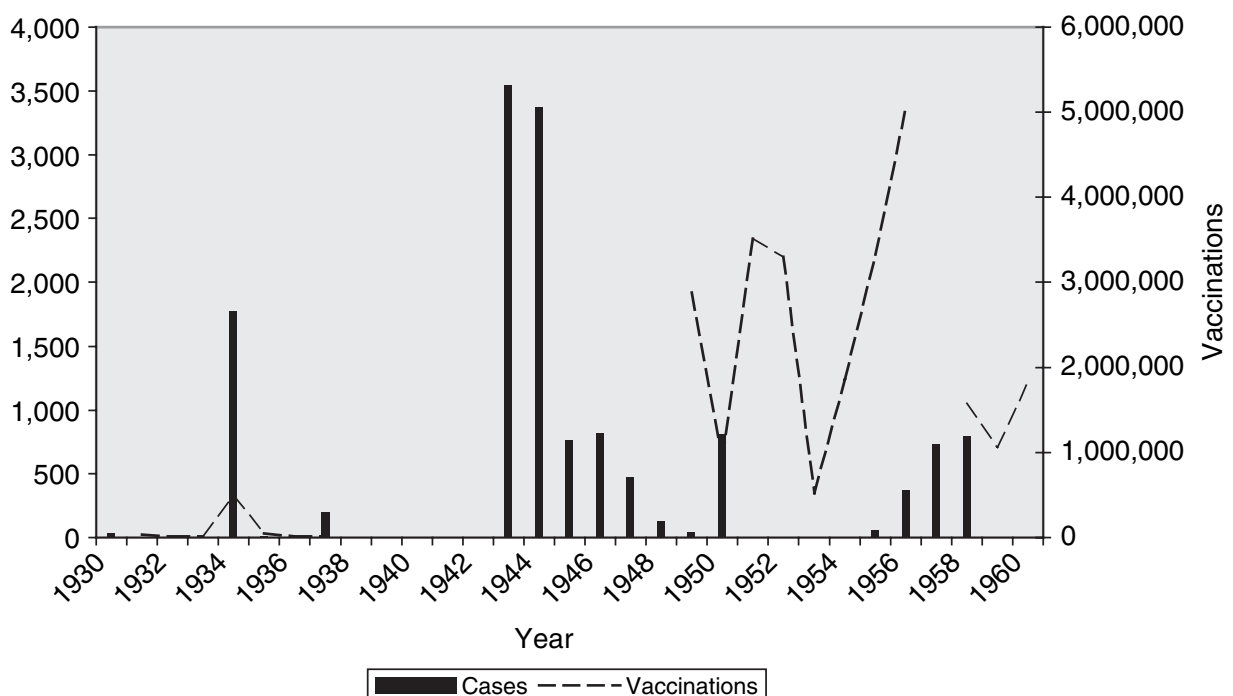

Figure 4

Smallpox cases and vaccinations, Uganda, 1931-58

(population: $3,470,689$ in $1931 ; 5,140,000$ in 1951)

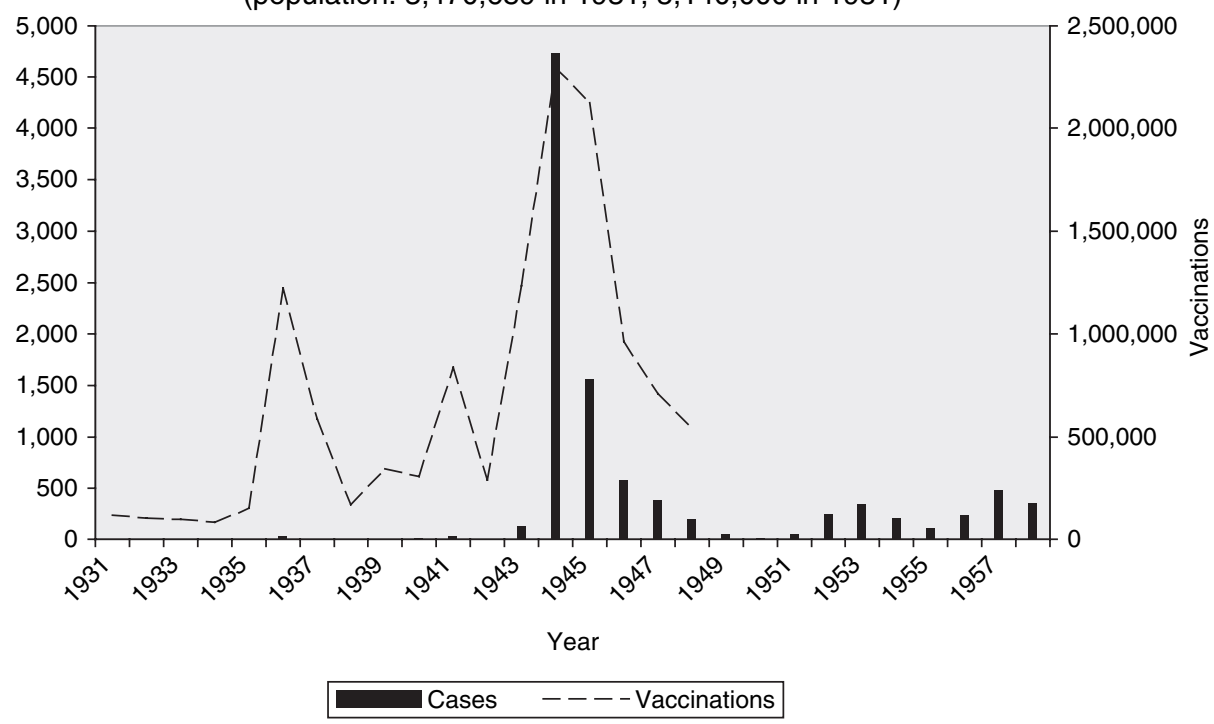

Figure 5 
Smallpox in Africa during Colonial Rule

Smallpox cases, N.Rhodesia, 1929-58

(population: $1,331,229$ in 1930; $1,631,146$ in 1946)

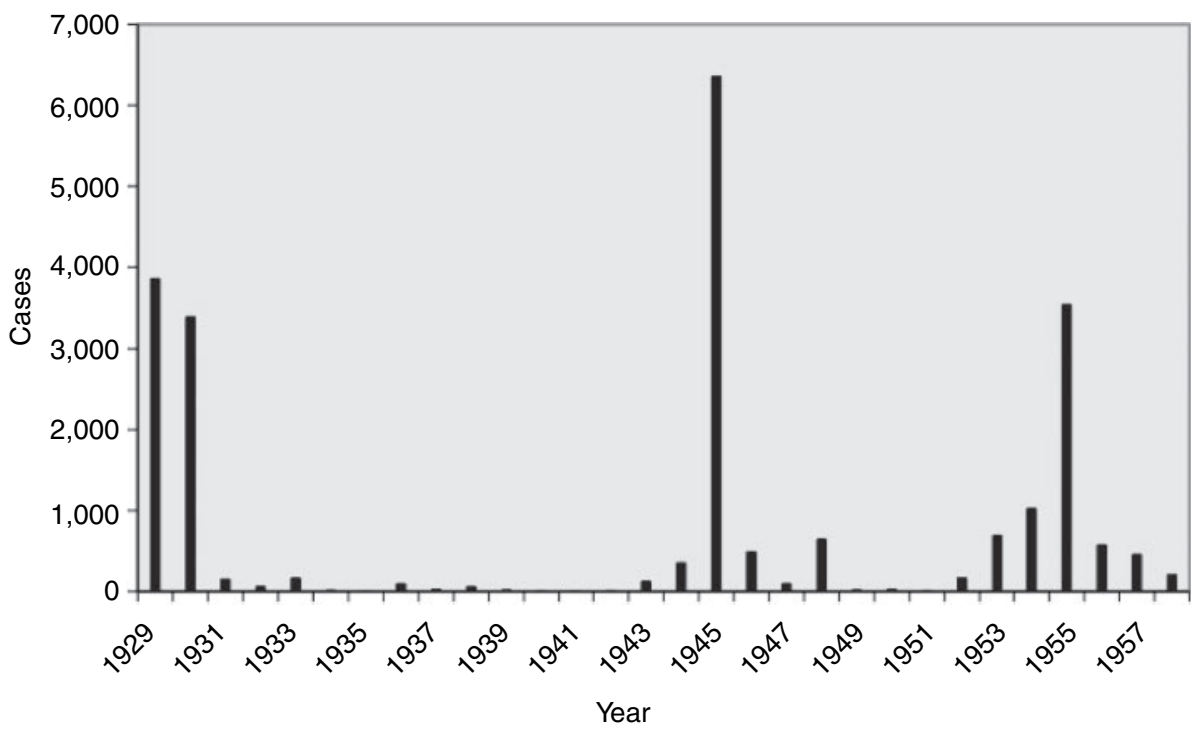

Figure 6

Smallpox cases and vaccinations, Tanganyika, 1929-58 (population: 4,740,726 in 1929; 7,079,557 in 1949)

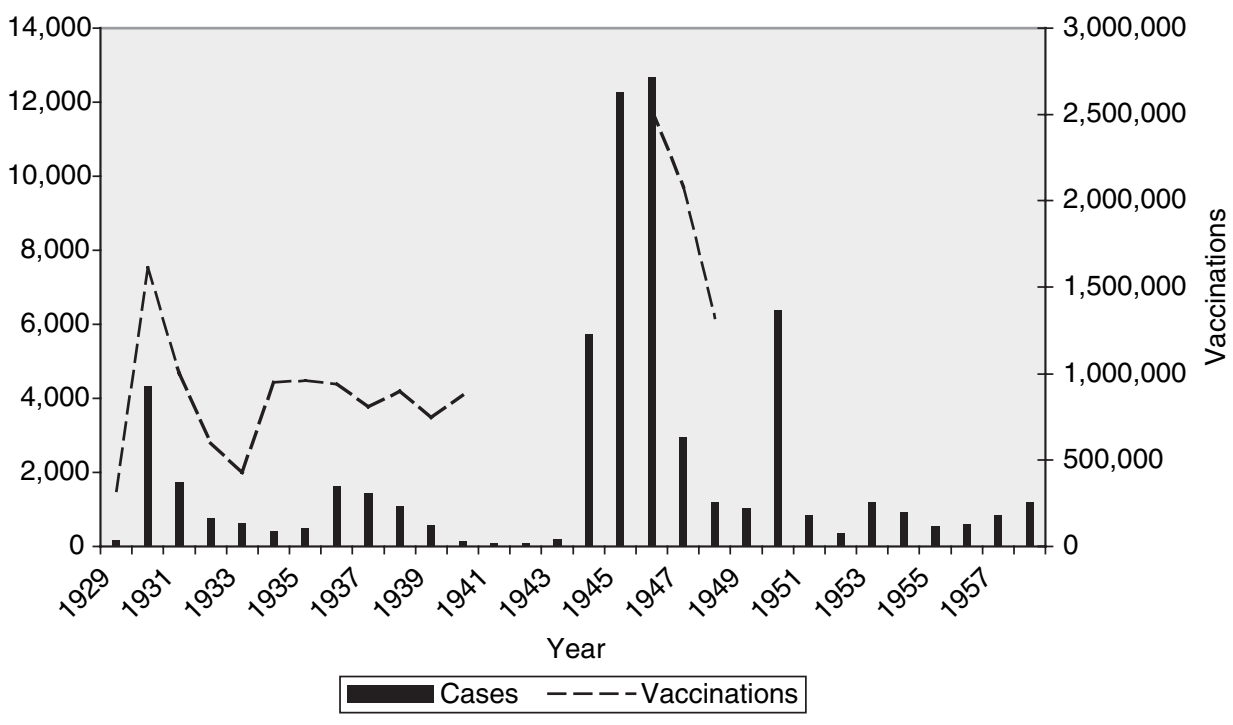

Figure 7 


\section{William H Schneider}

Smallpox cases and vaccinations, Nigeria, 1927-58

(population: $20,224,367$ in $1935 ; 31,180,000$ in 1952)

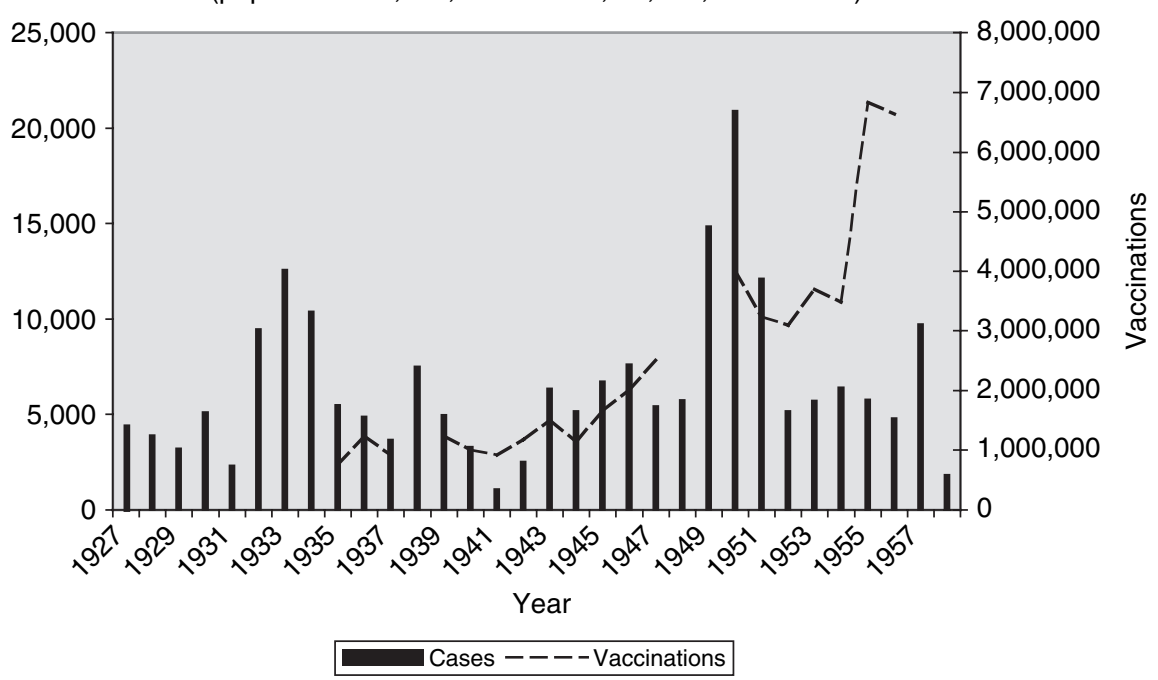

Figure 8

Smallpox Cases and Vaccinations, French West Africa, 1925-1957 (population: $13,476,483$ in 1927; 16,138,373 in 1940; 19,419,120 in 1954)

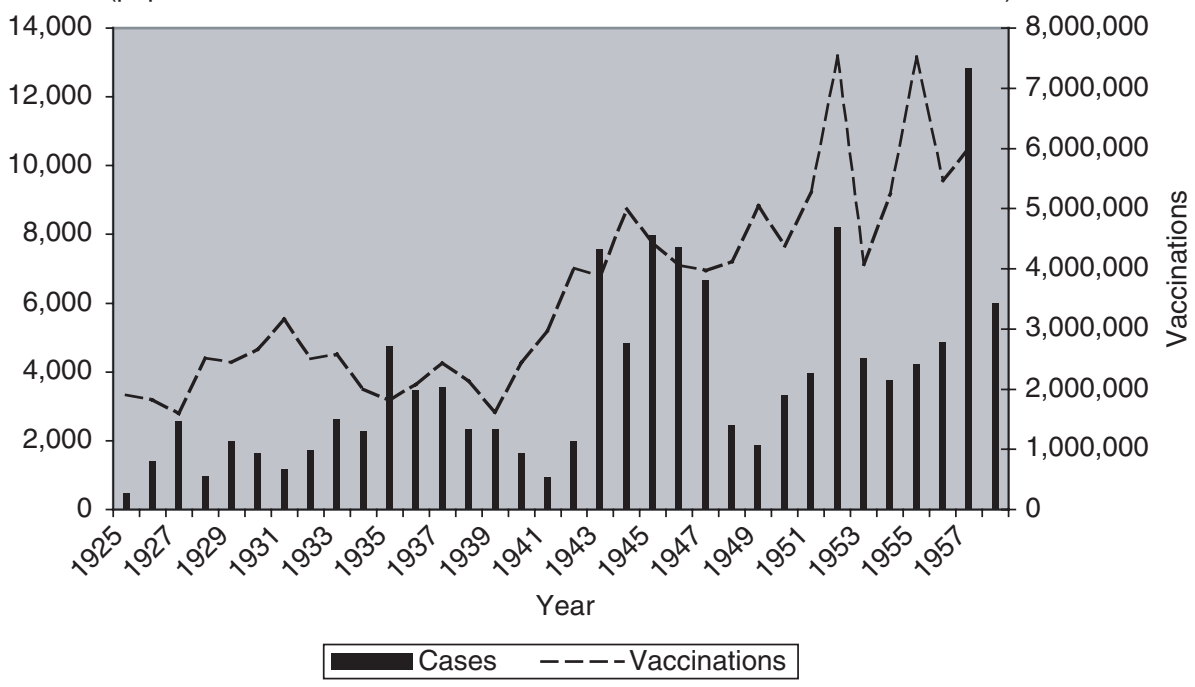

Figure 9 
Smallpox in Africa during Colonial Rule

Smallpox Cases and Vaccinations, Senegal 1927-1957

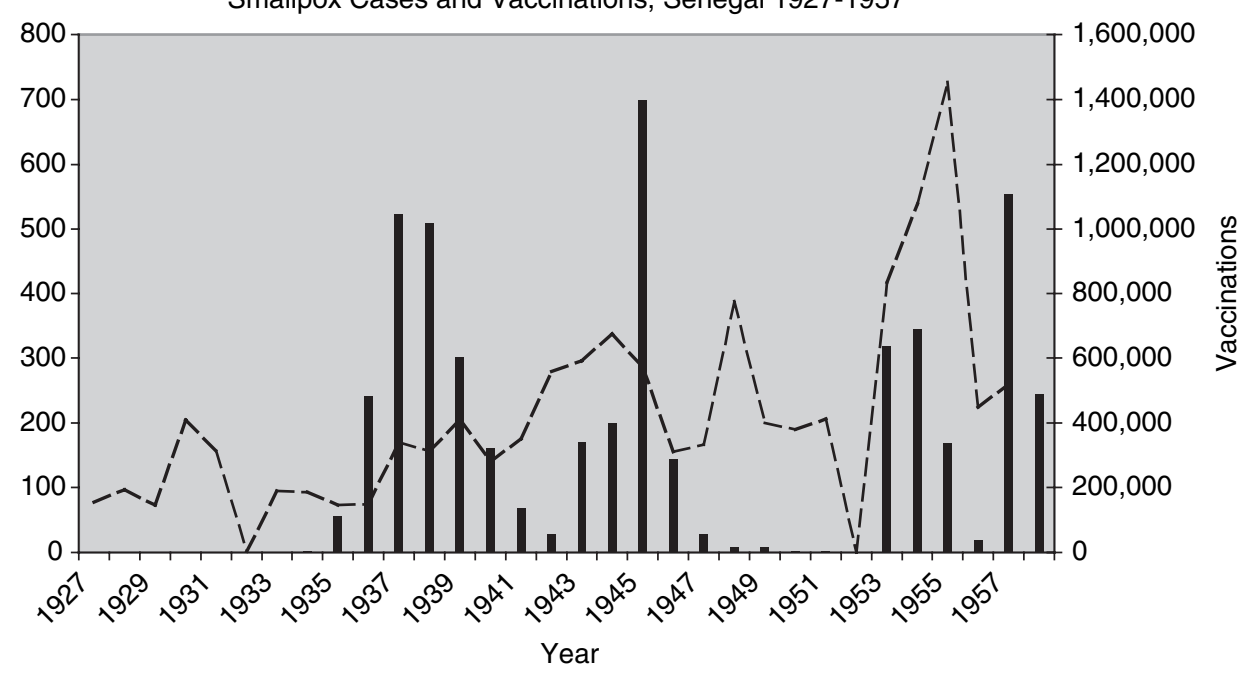

Cases ---- Vaccinations

Figure 10

Smallpox cases and vaccinations, Cameroon, 1925-58

(population: 2,230,000 in 1926; $5,426,00$ in 1957)

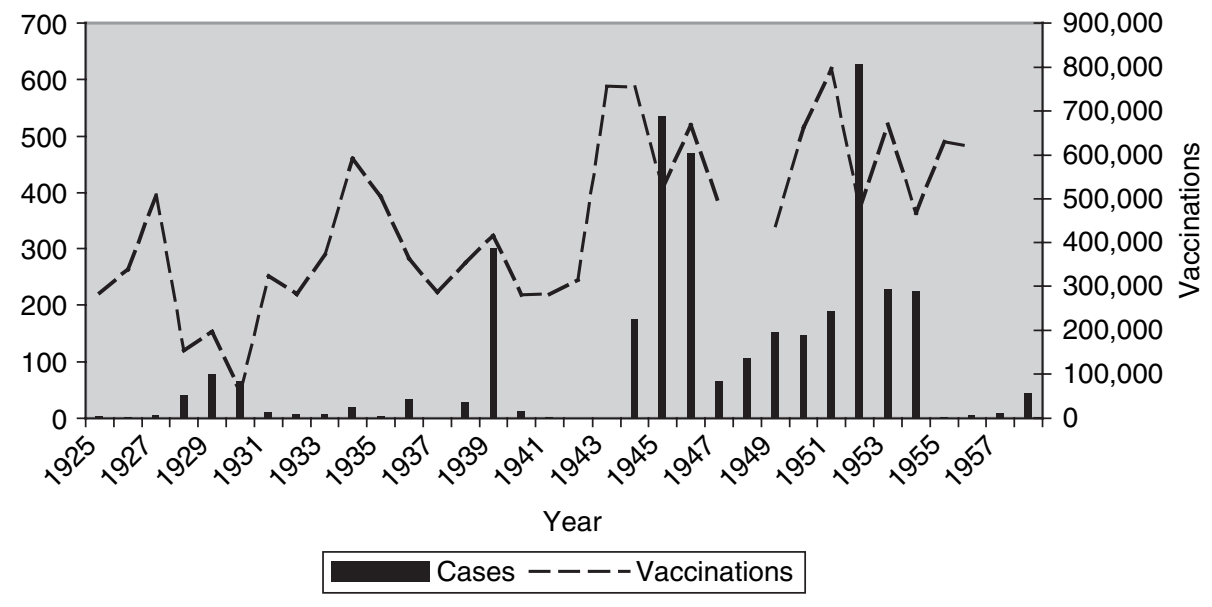

Figure 11 


\section{William H Schneider}

Smallpox Cases and Vaccinations, Ivory Coast, 1925-1957

(population: $1,722,931$ in 1927; 2,447,961 in 1954)

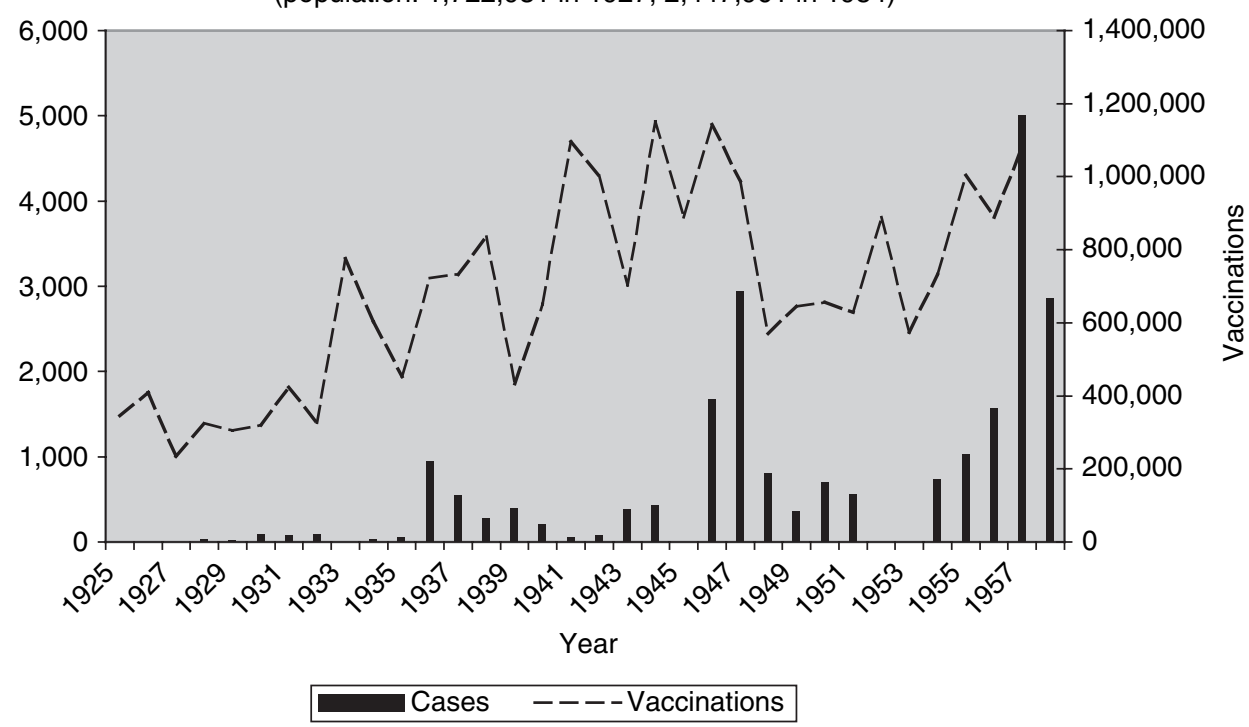

Figure 12

Smallpox Cases and Vaccinations, Dahomey 1925-1957

(population: 977,794 in 1927; 1,548,543 in 1952)

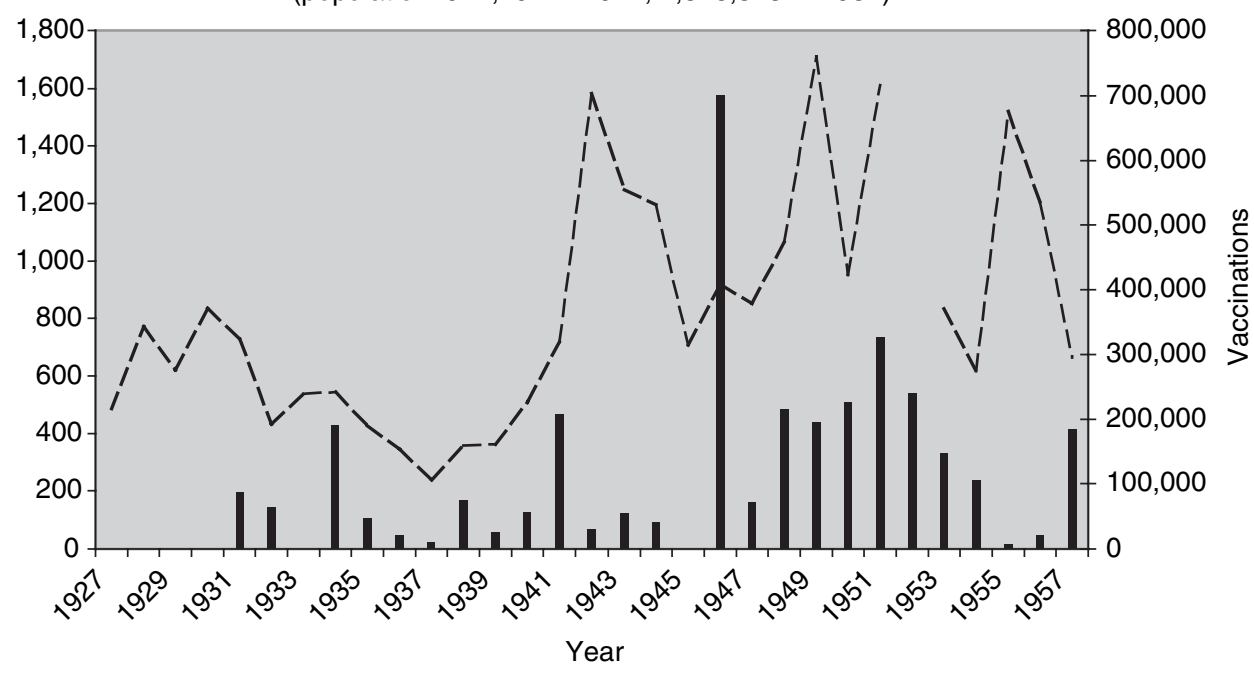

Cases - - - Vaccinations

Figure 13 
Smallpox in Africa during Colonial Rule

Smallpox Cases and Vaccinations, Guinea 1926-1958

(population: 2,093,726 in 1927; 2,253,159 in 1954)

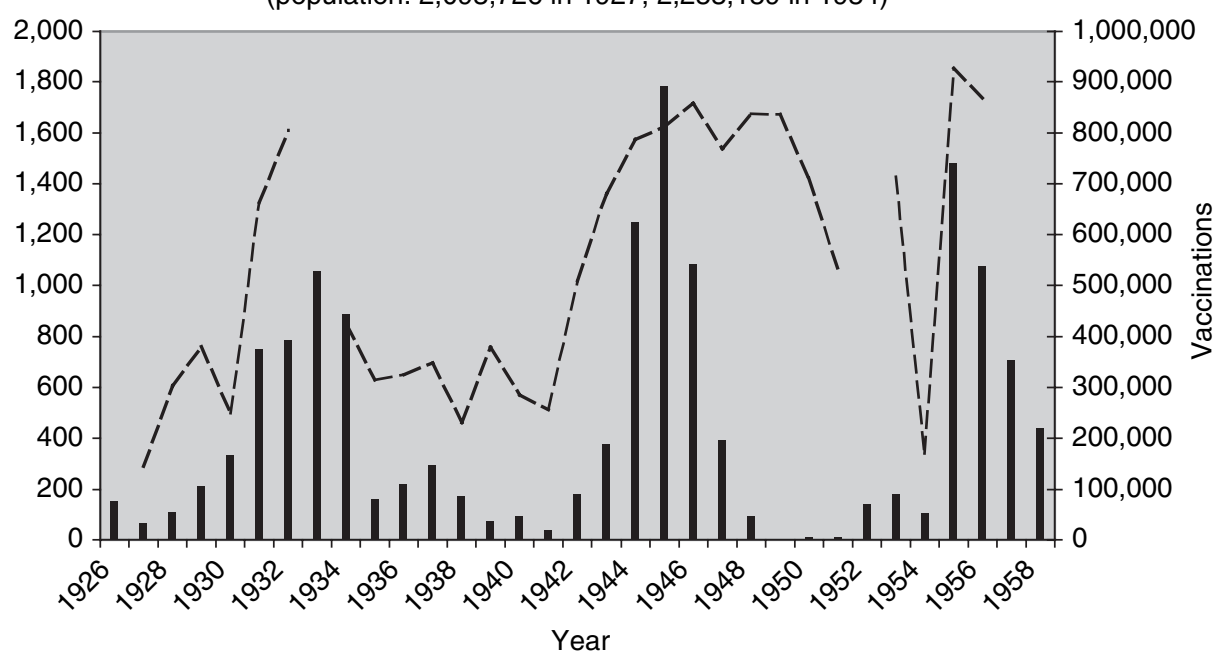

Cases - - - Vaccinations

Figure 14

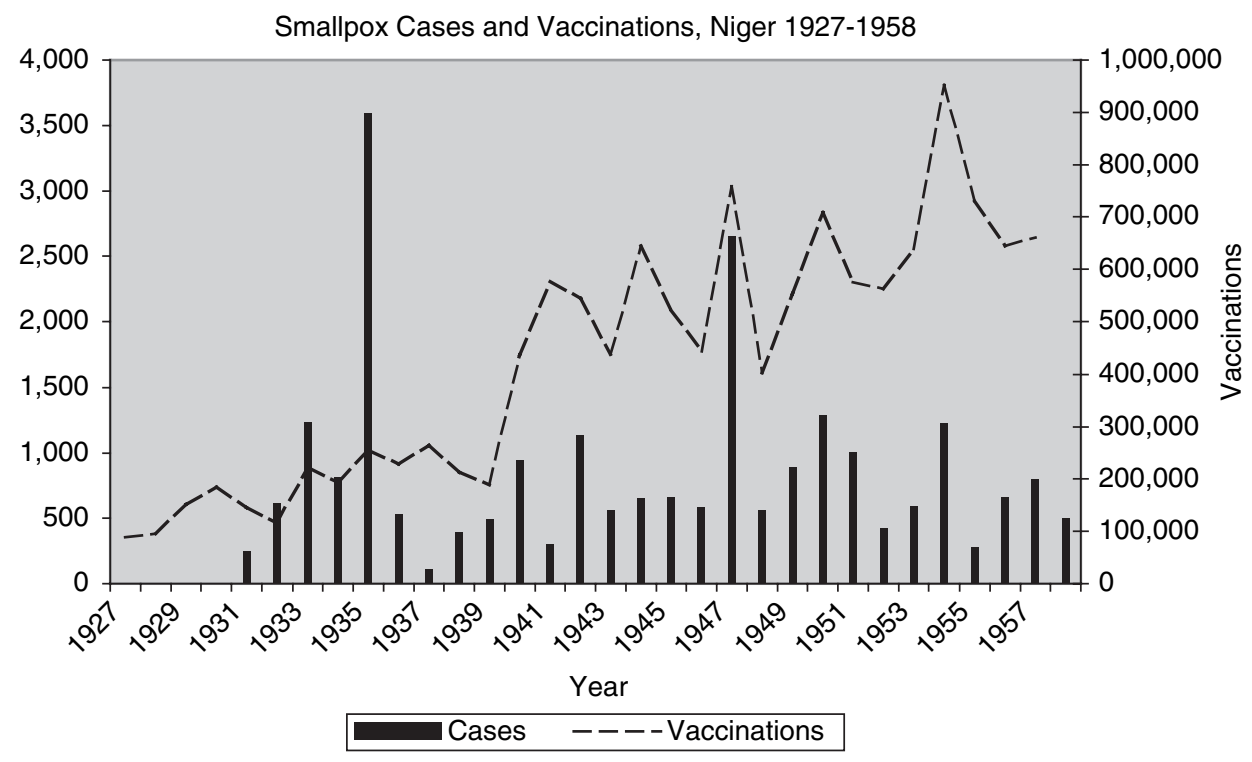

Figure 15 


\section{William H Schneider}

Smallpox Cases and Vaccinations, French Soudan 1927-1958

(population: 2,632,737 in 1927; 3,451,238 in 1951)

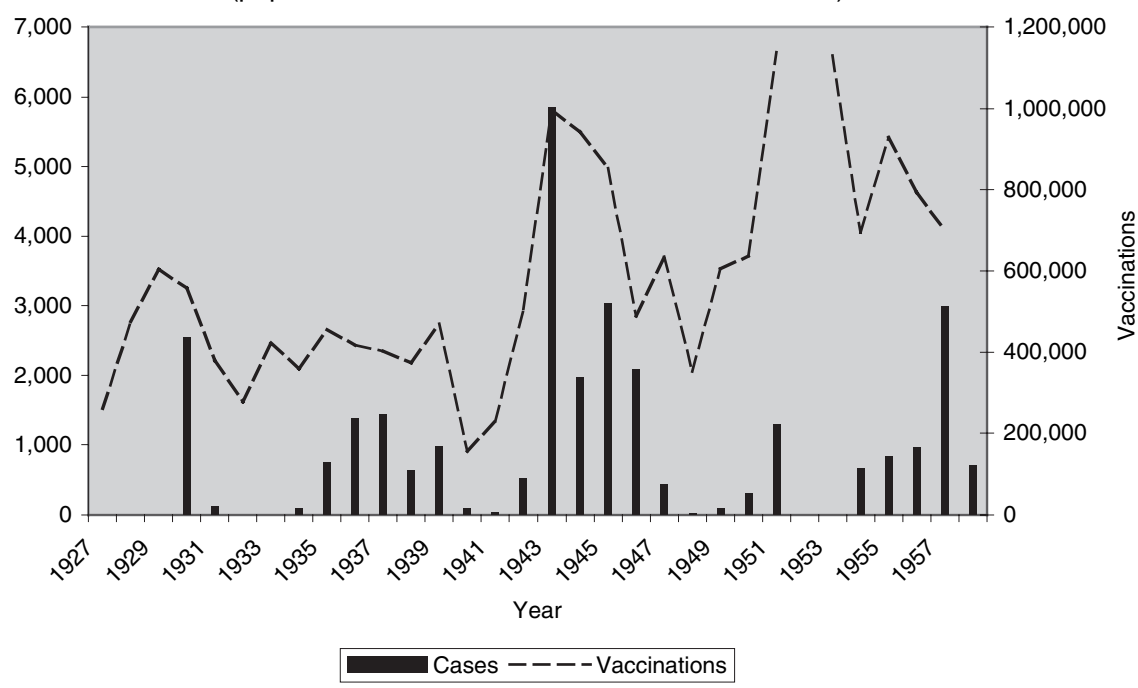

Figure 16

Smallpox cases and vaccinations, Chad, 1929-58

(population: $1,073,120$ in 1931; 2,579,600 in 1958)

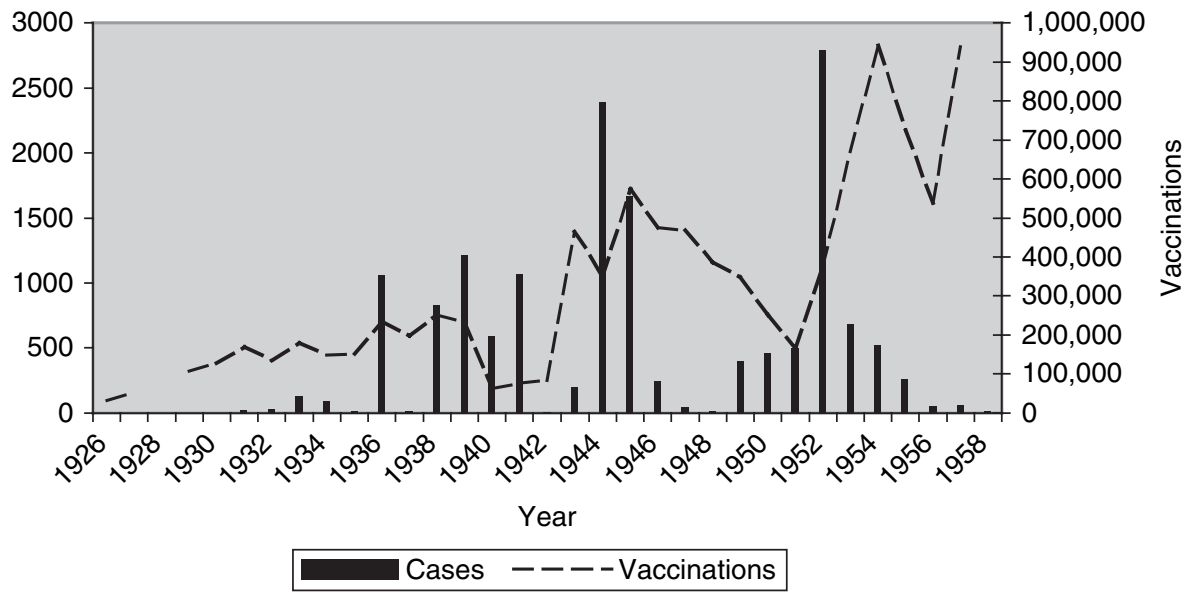

Figure 17 
Smallpox in Africa during Colonial Rule

Smallpox cases and vaccinations, Belgian Congo, 1918-58

(population: $7,700,000$ in 1925; 13,540,182 in 1958)

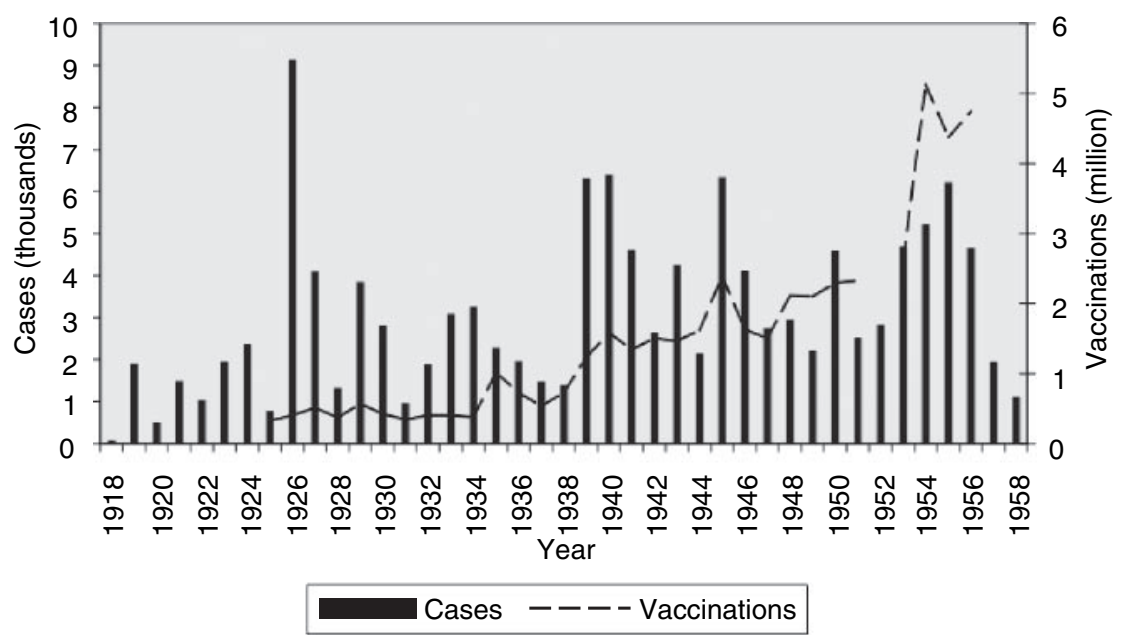

Figure 18 